\title{
Afonso o Sabio na lírica trobadoresca galego-portuguesa: da historia literaria á política cultural
}

\author{
Henrique Monteagudo \\ Instituto da Lingua Galega/Universidade de Santiago de Compostela
}

DOI: $10.17075 /$ gtax.2021.010 

Afonso o Sabio foi o promotor máis decisivo do emprego do castelán na documentación instrumental e do seu cultivo na prosa. A súa acción neste terreo foi da man do seu proxecto político de reforzo do poder da monarquía fronte á aristocracia e a igrexa1. Por outra banda, mostrou unha preferencia case exclusiva polo galego como lingua poética e foi un dos patrocinadores máis sobranceiros da lírica trobadoresca galego-portuguesa. Estas últimas facetas foron intensivamente estudadas nunha morea de traballos, parte dos cales serán citados ao longo da presenta achega, mais, aínda así, continúan sendo merecentes dunha reconsideración global desde o punto de vista da súa política cultural (Miranda 2012: 15-18). Desde a perspectiva inversa, o balance do papel do rei na evolución histórica da lírica galego-portuguesa raramente pasa dunha ben merecida - pero superficial- valorización encomiástica. Ao noso parecer, unha abordaxe que teña en conta o primeiro aspecto pode ser útil para equilibrar criticamente tal balance.

No presente contributo propómonos achegar elementos cara a este último obxectivo, coa plena consciencia de que para atinxilo cumpriría repensar unha serie de cuestións tanto do proxecto afonsino canto da historia daquel complexo fenómeno cultural. Entre estas, imos considerar, de xeito preliminar, as seguintes: a) a evolución do fenómeno trobadoresco durante o reinado de Afonso e por efecto das súas iniciativas nese terreo; b) a utilización da lírica trobadoresca ao servizo das políticas do rei; c) a significación, dentro do programa afonsino, das Cantigas de Santa María (CSM). Non pretendemos pechar ningunha destas cuestións, senón, ao contrario, abrilas ao debate, apoiándonos, loxicamente, nas valiosas propostas xa adiantadas neste sentido.

\section{O ASCENSO DA XOGRARÍA GALEGA NA CORTE DE AFONSO O SABIO}

Desde as súas orixes a finais do século XII, no noroeste da Península Ibérica existiu unha tradición de lírica trobadoresca autóctona que se expresou en

1 A bibliografía sobre este asunto é vastísima. Entre as mellores sínteses, pode verse Procter 2002: 13-18; Deyermond 1981: 154-173; Lapesa 1981: 237-247; Márquez Villanueva 1995 (especialmente, as pp. 35-42), e a panorámica de Fernández-Ordóñez 2013. 


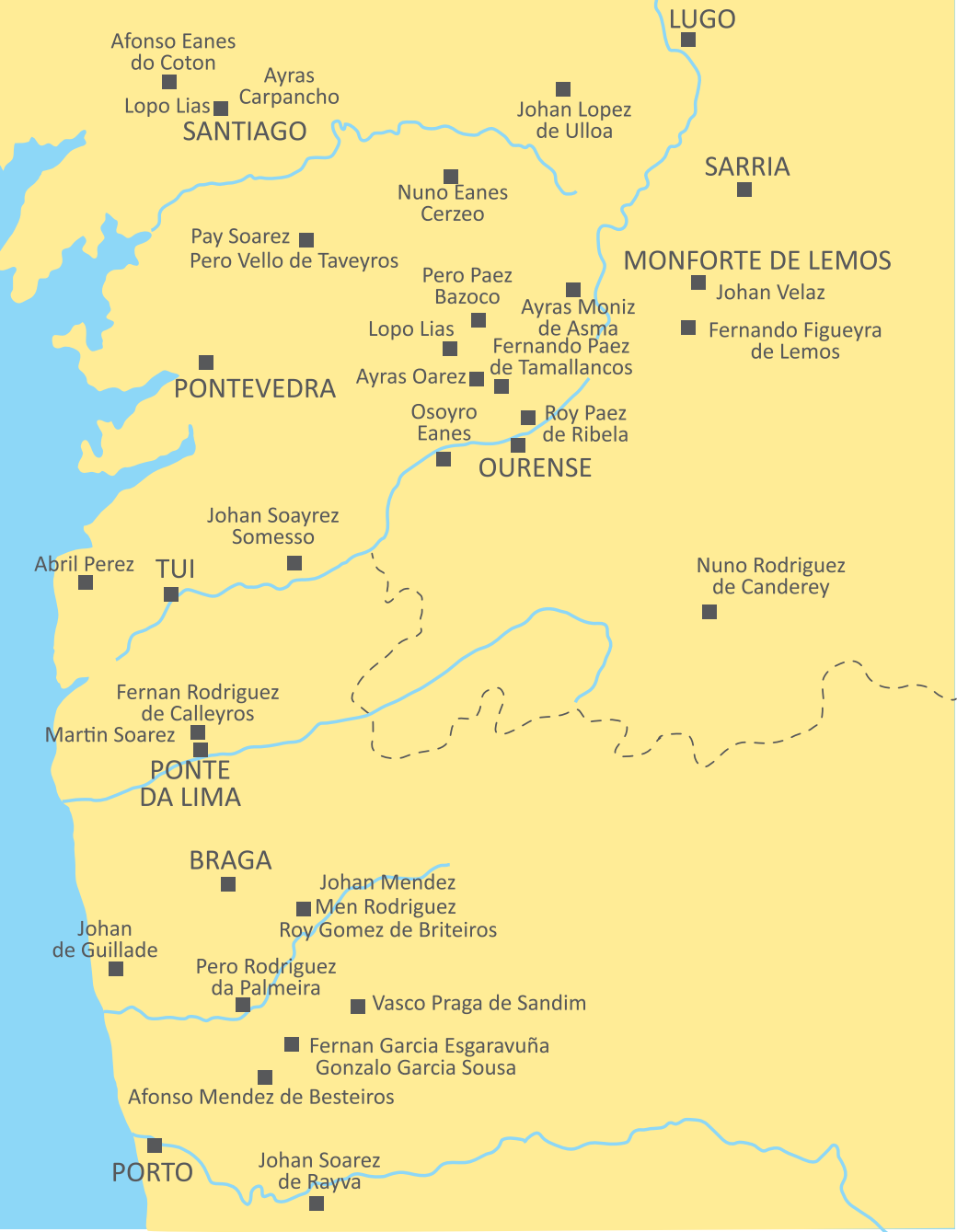

Mapa 1. Trobadores antigos. 
galego-portugués. Conforme o testemuño dos cancioneiros, as primeiras xeracións de trobadores, que floreceron entre 1175 ca. e 1225ca., estaban constituídas exclusivamente por nobres, entre os que se contan algúns magnates e unha maioría de cabaleiros de rango medio ou inferior, case todos orixinarios do occidente da Galecia (mapa n. $\left.{ }^{1}\right)^{2}$. A novidade foi acollida na corte de Afonso IX (derradeiro rei de León e Galicia, 1188-1230), o que parece que non aconteceu na corte real portuguesa. A segunda xeración trobadoresca, activa entre 1225 e 1240, estivo nutrida maiormente por «uma nobreza secundaria, de infanções e de simples cavaleiros», que producía os seus cantares «em regime de exclusividade» nos «paços de alguns magnates portugueses e galegos» (Oliveira/Miranda 1995: 500-501)². Deste xeito consolidábase

um processo de codificação literário-ideológica e um percurso de definição social e geográfica que irão, ao longo das décadas seguintes, identificar emblematicamente o galego-português e a poesia que nele se exprime com a proclamação por excelência da visão do mundo e da vivência aristocráticas não apenas portuguesa e galega, mas alastrando às terras vizinhas de Leão e Castela [...] onde a senhorialização territorial se afirmava mais forte e a curialização da nobreza se verificava menos eficaz do que no centro da península (Ferreira 2012: 6).

Fernando III, rei de Galicia e León desde 1230 (érao de Castela desde 1217) ata 1252, deparou unha acollida máis ben morna ao fenómeno trobadoresco na súa corte 4 . Pola contra, o seu primoxénito, o príncipe Afonso, xa na década de 1240, durante a súa etapa de infante, se arrodeou dun animado cortexo de trobadores, e durante o seu reinado (1252-1284) converteu a súa corte no centro máis importante do trobadorismo na península ibérica 5 . Segundo os cálculos de Oliveira, dos setenta e tres trobadores e xograres galego-portugueses que Tavani considera activos entre 1240 e 1280, polo menos corenta e seis pasaron por ela ${ }^{6}$. Entrementres, o seu xenro

2 Michaëlis 1990: II, 615-628; Tavani 1986: 249-255; Miranda 2004: 59-69, Oliveira 1995: 64-68 e Monteagudo 2008: 313-415 e 2014: 13-29, 36-40, 54-66 y 118-124. Oliveira/Miranda 1998, Miranda 2004: 13-57 e Oliveira 2001: 65-95 postulan que a primeira xeración floreceu nas cortes aristocráticas do centro-norte da Península, hipótese refutada directamente por Souto 2011a e 2012a e indirectamente por Monteagudo 2008: 341-359.

3 Oliveira 1995: 68-75 e 2001: 97-110.

4 Menéndez Pidal 1924: 186 e 191; Beltrán 2005: 39. Ambos os dous se refiren á lírica occitana, pero pretenden que este rei tivo interese na lírica galego-portuguesa. Secomasí, as páxinas que Menéndez Pidal dedica a esta (1924: 191-212), salvo no referente a Pero da Ponte, non mostran nada da súa suposta relación coa corte de Fernando III. Canto ao libro de Beltrán, o enteiro capítulo sobre «La corte de Fernando III» ten moi pouco que ver co tema enunciado. Pola súa banda, Alvar chega a suxerir que Fernando III é culpable do que denomina «fracaso lírico de Castilla» (1984: 6-7).

5 Sobre a corte de Afonso infante, véxase Alvar 1985 e, sobre todo, Oliveira 2010a e 2010b. Sobre a corte de Afonso como rei, véxase Alvar 1984; Beltrán 2005: 94-301; Oliveira 2010c e 2015.

6 Tavani 1986: 262; Oliveira 2010c: 69-72. 
Ferrol

- Fernando Esquio

Burgo do Faro

Pero Garcia d’Ambroa

Vasco Praga de Sandim

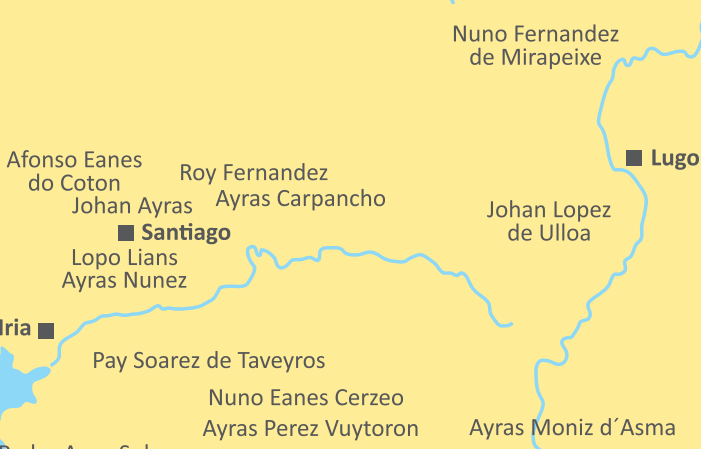

Pedro Anes Solaz

Pero Paez Bazaco

Fernando Figueyra de Lemos

Payo Gomez Chariño

- Monforte

Pontevedra Fernan Paez de Tamallancos

Roy Paez de Ribela Pero Vivyaez

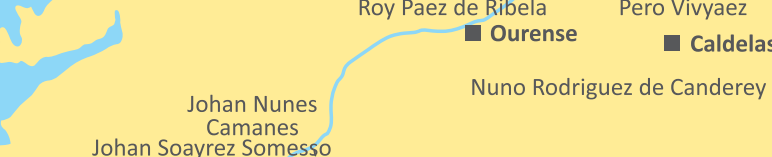

Johan Soayrez Somesso

[Gonçalo Tui Golparro Mendez d'Eixo]

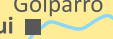

\section{Estevan}

Perez Froian

Ponte

Fernan Rodriguez de Calleyros

Johan Perez d'Aboim

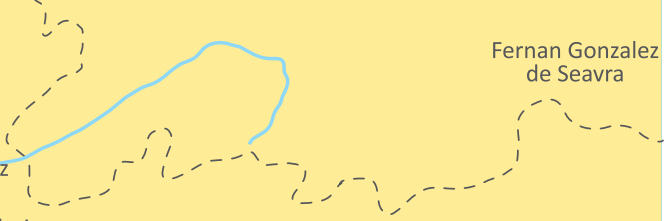

Fernan Fernandez Cogominho
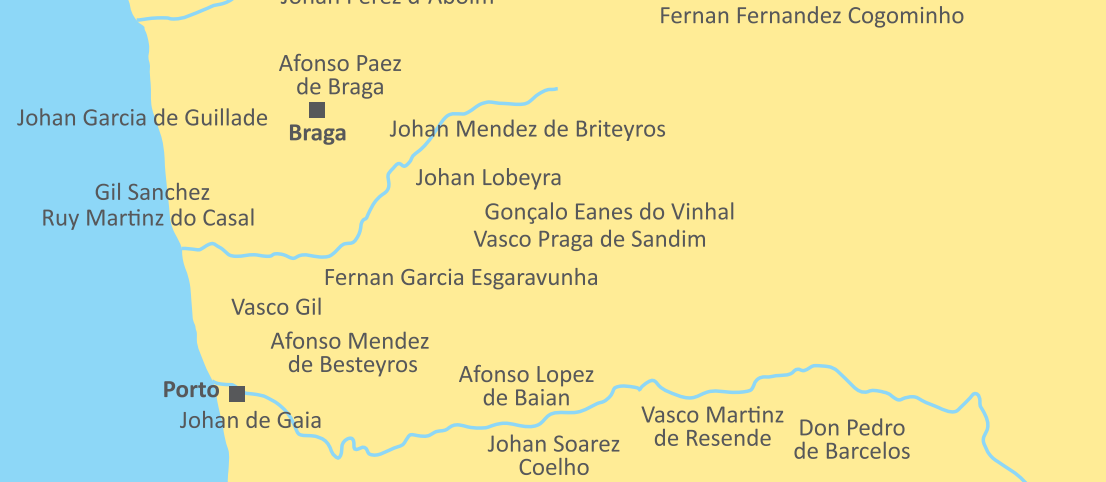

Mapa 2. Trobadores do noroeste. 
Afonso III o Bolonhês, rei de Portugal no período coetáneo (1248-1279), tamén ofreceu unha acollida cálida, aínda que menos efusiva, aos trobadores. Deste xeito, desde a metade do século XIII a lírica galego-portuguesa tendeu a orbitar á volta das cortes rexias, e non tanto arredor das cortes da media e pequena nobreza galaica e do noroeste peninsular en sentido largo ${ }^{7}$. De todos os xeitos, os seus cultivadores continuaron sendo na súa inmensa maioría orixinarios das terras da vella Galecia ata as últimas xeracións, activas na primeira metade do século XIV, cando a achega galega estiña ao paso que medra a do Portugal ao sur do Douro (mapa no 2 ).

A corte trobadoresca do Sabio foi máis nutrida, diversa e animada ca a do Bolonhês. En Portugal a tendencia centralizadora do padroado rexio traduciuse nun maior peso da aristocracia, nomeadamente da nobreza de corte. Alí salientaron trobadores como Afonso Lopez de Bayan, Johan Soarez Coello, Vasco Gil de Soverosa, Men Rodriguez de Briteyros ou Johan Perez de Avoyn (Oliveira 2009). Como consecuencia da acentuación do seu carácter aristocrático, en Portugal a lírica trobadoresca seguiu aferrada á cantiga de amor, calcada dos moldes occitanos. Unha das escasas novidades introducidas foi o cultivo da pastorela, un tipo de composición extremadamente convencional, de sabor distintivamente aristocrático, importado do norte de Francia (Gonçalves 2016: 441-453).

Na corte de Afonso o Sabio o panorama era máis heteroxéneo, pois, ademais da implicación do propio monarca, da participación de varios trobadores occitanos e dun importante séquito de cabaleiros galegos e portugueses, destacou a febril actividade dunha xograría maioritariamente galega e con forte presenza compostelá (mapa n.ㅇ 3) ${ }^{8}$. Desde a década de 1240, primeiro en territorio galego e despois na corte de Afonso o Sabio, a base social da lírica trobadoresca sufriu unha profunda transformación, ao entraren en xogo creadores cun perfil social ben diferente ao dos primeiros trobadores. Isto non deixou de ter efectos sobre a propia materia creativa. Da man da puxanza da xograría, en Galicia e na corte de Afonso, a canción de amor cedeu en importancia en relación tanto ao cantar satírico canto á cantiga de amigo, esta última vinculada a unha inveterada tradición literaria indíxena.

A puxanza da xograría galega prodúcese antes no propio territorio galego e aquí atinxe a súa expresión máis vistosa. Investigacións recentes están poñendo de vulto a capital achega do burgo de Compostela. Neste sentido, non pode deixar de chamar a atención a abraiante diversidade social do trobadorismo compostelán. Vencellados con Santiago, pola orixe ou a residencia, estiveron trobadores cabaleiros como Osoyro Eanes, Ayras Carpancho, Lopo Lias ou Afonso Eanes do Coton, clérigos como Ayras Nunez, Roy Fernandez, Martin Moxa, Sancho Sanchez ou Pae da Cana, segreis como Pero da Ponte e Bernal de Bonaval, xograres como Juyão Bolseyro

7 Oliveira 1985: 75-79; Ferreira 2012: 6.

8 Tavani 1986: 256-264; Oliveira 1989: 9, 29 e 32; Oliveira 1995: 75-79 e Oliveira 2010c: 68-72. Sobre un total de sesenta autores de naturalidade galega, este autor calcula que vinte e nove son xograres, vinte e sete trobadores e catro clérigos. Véxase tamén Oliveira 1995: 76-77 e Oliveira 2001: 178. 
Pedro Amigo de Sevilla

Pero d'Ambroa

Pero de Armea

Pero da Ponte Johan Ayras

Juyao Bolseyro

Bernal de Bonaval

Johan Romeu

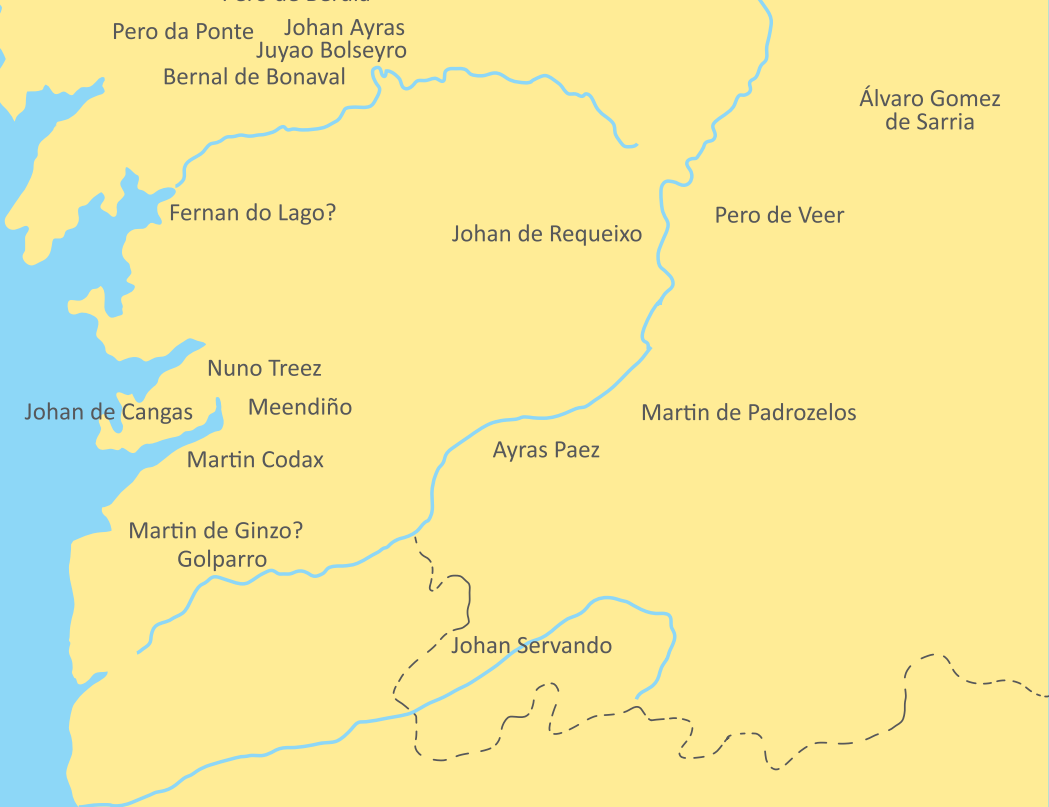

Mapa 3. Xograres galegos.

e Pero de Berdia e burgueses como Johan Ayras9. A devandita serie cobre todo o século XIII, desde os inicios ata o final: aos tres primeiros, os máis antigos, non se lles coñece contacto coas cortes reais (excepto talvez a Osoyro Eanes coa corte de Afonso de Galicia e León), pero boa parte dos demais pasaron pola corte do Sabio, algúns estiveron tamén na do seu fillo Sancho IV e o último incluso visitou a de don Denis. En todo

9 Lorenzo 1993, Vieira 1999, Souto/Vieira 2003, Souto 2011b e 2012b, Vieira, Morán e Souto 2012. Johan Ayras é o autor con máis composicións nos cancioneiros, despois de don Denis, con oitenta e unha cantigas. É extraordinario que un trobador identificado nos cancioneiros como «burgués de Santiago» chegase a producir e a reunir unha obra tan avultada. Sobre a directa conexión de Pae ou Pay da Cana con Afonso o Sabio, véxase o artigo de Francisco Hernández neste mesmo volume. 
caso, tal continuidade histórica e tal diversidade socio-cultural non se documenta en ningún outro centro do trobadorismo galego-portugués.

Á relación dos autores composteláns cómpre engadir dunha banda outros xograres galegos que destacaron na corte de Afonso e doutra, o tropel dos que probablemente exerceron fóra desta, dos cales a penas sabemos nada. No primeiro grupo salienta o trío procedente do arco ártabro, Pero de Anbrõa, Pero de Armea e Pedro Amigo de Sevilla, talvez os últimos representantes do círculo congregado ao redor da corte dos Traba, cuxo derradeiro gromo foi Rodrigo Gomez de Trastámara (morto en 1261), ben que o primeiro parece que estivo vencellado a outro nobre galego de grande relevo, Munio Fernandez de Rodeiro ${ }^{10}$. Por suposto, houbo máis xograres na corte de Afonso, como Johan Baveca ou Lourenço, de cuxa naturalidade galega non temos unha certeza absoluta.

O segundo grupo está constituído pola riola dos xograres cultivadores da cantiga da amigo paralelística, grupo a un tempo escuro pola humilde orixe social e a conseguinte falta de relevo histórico dos seus compoñentes, e brillante polo superior talento poético dalgúns dos seus nomes, como Martin Codax ou Meendiño. Se na corte de Afonso a preferencia pola cantiga satírica se converteu na principal novidade literaria, sen dúbida a innovación máis valiosa traída polos xograres veu da man da cantiga de amigo paralelística, soberbiamente cultivada polos xograres galegos que exerceron no ámbito local e que semella que non foi especialmente apreciada polo Rei Sabio.

De todos os xeitos, a promoción dos humildes xograres, de simples executantes das composicións elaboradas polos trobadores de rango aristocrático, a creadores das súas propias cancións, supuxo unha novidade revolucionaria, e Afonso o Sabio xogou nela un papel fundamental. Tratábase dun salto cualitativo no status socio-literario da xograría. Desde o inicio do cultivo da lírica trobadoresca víñase observando unha distinción estrita entre dúas categorías socio-culturais rixidamente xerarquizadas: trobadores e xograres. En principio, como observou Carolina Michaëlis, «segundo a theoria sustentada pela classe privilexiada, trobador era quem cultivava a poesía e a música, creando ou inventando obras novas, como dilettante, i. e., com inteira independencia; por gosto, sem ideia alguma de lucro». O trobador era un cabaleiro; pola contra, o xograr era un individuo da clase servil, cuxo «officio consistia em

10 Aínda está vivo o debate sobre a identidade de Pero Garcia de Anbrõa e Pedro de Anbrõa, ao primeiro dos cales, aparentemente un trobador que podería estar documentado antes de 1240, se atribúe nos cancioneiros unha cantiga de amor, mentres que o segundo, con toda seguranza un xograr ou segrel que estivo activo entre 1240 e 126 aproximadamente, aparece como autor de unha cantiga de amigo, unha tenzón e once cantigas satíricas (máis tres perdidas). Sobre isto véxase Souto 2006 e Ventura 2014. Sobre Pedro Amigo de Sevilla, véxase Beltrán 1993. Sobre Pero de Armea, Couceiro 1993. En todo caso, non nos cabe dúbida de que existiu un xograr ou segrel Pero de Anbrõa activo na corte de Afonso, e tamén parece claro que estes autores estiveron relacionados entre si. Sobre Munio Fernandez de Rodeiro e Rodrigo Gomez de Trastámara nos tempos de Afonso o Sabio, véxase o artigo de Francisco Hernández neste mesmo volume. 
tanger varios instrumentos de música e em cantar versos alheios» (Michaëlis 1990: II, 628-629).

A novidade quizais veu facilitada pola aparición previa dunha categoría intermedia, a de segrel. O debate sobre o significado deste termo no ambiente peninsular vén de lonxe, e bascula entre quen o entende como designación dunha categoría específica, híbrida, que se oporía tanto ao xograr - porque o segrel pertencía á nobreza ínfima e tiña competencia para trobar-coma a do trobador - porque recibía don pola súa actuación -, e quen o interpreta como a designación adoptada para os xograres aos que se recoñecía competencia para trobar ${ }^{11}$. Nos textos trobadorescos o termo aparece en poucas ocasións, case sempre empregado como sinónimo de xograr executante, non compositor (B 144, V 1021, B 1514, B 1515). Non obstante, tamén aparece aplicado a catro compositores: Pero da Ponte, Bernal de Bonaval, Pero de Anbrõa e Picandon. Curiosamente, os dous primeiros eran composteláns, o terceiro tamén era galego e o cuarto era un xograr ao servizo do trobador italiano Sordello.

Pero da Ponte, nunha tenzón co cabaleiro Afonso Eanes do Coton ${ }^{12}$, compostelán coma el (retéñase o dato), reivindícase como segrel e dá unha definición moi precisa do termo, que apuntala a primeira das dúas devanditas interpretacións, ben que restrinxe ese uso á «nossa terra» (Santiago? Galicia?): «en nossa terra, se Deus me perdon / a tod'o 'scudeiro que pede don / as mais das gentes lhe chaman segrel» [Anexo n.․ 16]. Ademais, Bernal de Bonaval é alcumado como segrel nunha tenzón que mantén con Abril Perez (B 1072, V 663) e nun maldizer que lle dirixe Ayras Perez Vuitoron (B 1475, V 1086); en ambas, o termo é empregado cunha clara connotación pexorativa. Tendo en conta a naturalidade dos poetas que acabamos de citar, se cadra o que aconteceu é que o termo adquiriu unha acepción particular no contexto galego.

En todo caso, unha proba de que estes segreis foron finalmente recoñecidos como trobadores de pleno dereito está na rúbrica que precede o cancioneiro dos xograres galegos incorporado á Compilación xeral da lírica trobadoresca, en que Bernal de Bonaval é cualificado como «primeyro trobador», o que implica que a designación de trobador non só se aplica a el, senón á totalidade dos autores incluídos neses cancioneiro (B 1062, V 653) ${ }^{13}$. Isto quer dicir que a denominación trobador xa non se refería á clase social, senón á competencia recoñecida na arte de trobar.

Este cambio non foi doadamente aceptado polos cabaleiros, que defendían o trobar como patrimonio exclusivo do seu estamento (Pidal 1924: 237-243). Non por casualidade, entre os temas preferidos das numerosas composicións satíricas do terceiro cuartel do século XIII salientan os ataques dos trobadores nobres con-

11 Resume a cuestión Oliveira 1993b, enviando a bibliografía máis relevante. Recentemente, retómaa Falcão 2019.

12 A tenzón era unha cantiga dialogada, tipicamente burlesca, composta por dous trobadores que compiten entre si en mordacidade e enxeño.

13 Sobre a xograría galega e o presunto Cancioneiro dos xograres galegos, véxase Oliveira 1987, 1989, 1994: 262-265 e 1998. 
tra os xograres. Aínda que o vituperio destes por parte aqueles é un tema recorrente na sátira trobadoresca, debe notarse que antes da puxanza da xograría o albo principal das invectivas eran as súas deficiencias como executantes. Por exemplo, o cabaleiro Martin Soarez búrlase do xograr Lopo nos termos seguintes: «Foy un dia Lopo jograr / a cas d'un infançon cantar; / e mandou-lh' ele por don dar / tres couces na garganta;/ e fuy-lh’ escass', a meu cuydar, /segundo com’el canta» (B1366 / V974). Durante o turbulento período de ascenso da xograría, os dardos apuntan tamén ás pretensións xograrescas de seren recoñecidos como trobadores. É ilustrativo o ataque do magnate Johan Perez de Avoyn contra o xograr Lourenço, un dos representantes máis significados da «nova» xograría (Falcão 2015): «Lourenço, soyas tu guarecer / como podias, per teu citolon, / ou ben ou mal, non ti digu' eu de non, / e vejo-te de trobar trameter;/ e quero-t’ eu desto desenganar: / ben tanto sabes tu que é trobar / ben quanto sab’ o asno de leer» (V1010).

O propio Afonso se burlou das pretensións dos segreis composteláns, personificadas en Pero da Ponte, en dúas célebres composicións: nunha acusouno de emborrachar a Afonso do Coton para asasinalo e roubarlle os seus cantares (B 485, V 68), noutra afeoulle: «vós non trobades come proençal, / mais come Bernaldo de Bonaval» (B 487, V 70) [véxase anexo n.o 14 e 15]. A crítica tense preguntado se o monarca non estará aquí singularizando un estilo de trobar especificamente compostelán, heterodoxo en relación cos modelos occitanos (Paredes 2010: 220-225 e 232-237).

Sexa como for, Afonso o Sabio acabou consagrando o recoñecemento dos xograres como trobadores mediante nun «decreto» poético, a Declaratio, promulgado en 1275 en resposta a unha Suplicatio do trobador occitano Guiraut Riquier. O rei sentencia que trobadores «son os que co corazón / saben tecer boas cobras / e facer danzas dobras, / fermosos sirventeses, / albas e tenzóns, / e compor letras e sons» ${ }^{14}$. Por parte, é probable que tamén favorecese a incorporación dos xograres aos cancioneiros, compilacións que inicialmente estaban reservadas aos cabaleiros. O primeiro paso nese sentido puido ser o acrecento do Cancioneiro da Ajuda, co engadido ao final de ciclos poéticos de autores coma Pero da Ponte, Roy Fernandez ou Martin Moxa $^{15}$. En definitiva, semella claro que a promoción da xograría resultaba congruente coa política decididamente anti-aristocrática do Rei Sabio. A súa utilización intensiva da lírica como arma de propaganda política apunta claramente no mesmo sentido, como veremos a seguir.

14 «so son aquel que.l cors / sabon de faire coblas / e de far dansas doblas / e sirventes valens / albas e partimens / e trobar motz e sos». A Suplicatio de Guiraut Riquier está editada por Alvar 1978: 133-156, a Declaratio de Afonso atópase na mesma obra, 178-189. A cita é das páxinas 188-189. Para a interpretación do decreto de Afonso, véxase Oliveira 1995: 36-41. Véxase tamén a tradución de Rodríguez Velasco 1999: 293-300.

15 O seu neto, o rei don Denis de Portugal, daría un paso máis nesa liña, decisivo, ao inserir un Cancioneiro de xograres galegos, individual e específico, no Cancioneiro xeral da lírica trobadoresca (Monteagudo 2019: 927-951). 


\section{AFONSO O SABIO E A LÍRICA TROBADORESCA: POESÍA E PROPAGANDA POLÍTICA}

Afonso foi el mesmo un trobador extraordinario, que compuxo corenta e catro cancións profanas ${ }^{16}$. Case todas elas teñen carácter satírico, coa nobreza e o clero como dianas das censuras máis furibundas, desde os cabaleiros desleais ata os coteifes covardes, e, por outra banda, desde o Papa ata o pornógrafo deán de Cádiz (Alvar 1984 e 1998). Unha preferencia tan marcada do rei pola cantiga satírica merece unha explicación: dunha banda pode responder a unha abordaxe predominantemente lúdica e política do seu cultivo; doutra, pode reflectir unha certa incomodidade ante a cantiga de amor, que tería adquirido carácter emblemático como expresión dos valores da aristocracia, constituíndo así unha especie de «bastião inexpugnável de uma cultura e de uma ordem que representavam um permanente desafio às instâncias de afirmação régia» (Ferreira 2012: 6).

Sexa como for, a vertente do uso político da lírica trobadoresca non só aparece na obra de Afonso, senón que foi cultivada por varios trobadores da súa corte, naturalmente, sempre ao seu favor. A corte lírica afonsina caracterízase por unha marcada predilección pola sátira, para a cal incluso se adaptou un novo tipo de cantiga, a tenzón. Aínda que abundan os estudos sobre episodios particulares e sobre composicións concretas, na nosa opinión falta unha visión xeral da faceta política da sátira trobadoresca ${ }^{17}$. Limitarémonos a esbozar algúns apuntamentos, enfocados cara aos litixios de Afonso cos dous poderes que combateu con máis teimosía: a igrexa, e, sobre todo, a nobreza.

O Rei Sabio tiña que ser bo coñecedor da vertente propagandística da lírica trobadoresca, amplamente explotada na lírica occitana. Carlos Alvar dá noticia de quince trobadores occitanos — sete dos cales visitaron a súa corte- que aludiron ao Sabio por un outro motivo nun total de sesenta composicións ${ }^{18}$. O mesmo estudoso propugna que, pola contra, os trobadores galego-portugueses ignoraron case totalmente os asuntos políticos ou se limitaron a tratalos de modo anecdótico (Alvar 1984: 19-20) ${ }^{19}$. A contrafío desta afirmación, o emprego da lírica como arma de propagan-

16 O inventario exacto do repertorio lírico profano de Afonso presenta algunhas dúbidas, xa que o número de tençons pode variar entre tres ou cinco, dependendo de se se identifica con el o interlocutor designado como «senhor» en cadansúa tençon con Pay Gomez Chariño (B1624/V1158) e Pero Garcia Burgales (B1383/V991). Véxase Alvar 1998: 17, e Oliveira 2013: 260-264. A transmisión deste repertorio foi azarosa, pois as súas composicións chegaron ás mans do seu bisneto, o conde Pedro de Barcelos, moito despois da súa morte, no segundo cuartel do século XIV, e en condicións bastante precarias. Foi don Pedro quen as integrou no Cancioneiro xeral da lírica.

17 Véxase Michaëlis 2004: 175-217; Tavani 1993; Lanciani/Tavani 1995: 105-118; Beltrán 2005: 123-232 e 2007: 13-52.

18 Como é de esperar, o asunto máis tratado nestas é a súa reclamación da coroa imperial. Véxase Alvar 1984 e 1977: 181-258, especialmente 257-258.

19 Este parecer aparece reiterado en Alvar 1998: 4-6. Concorda con el Lopes 1998: 263; Tavani 1993 é máis matizado. 
da política contaba con notables precedentes da tradición galego-portuguesa. Sen ir máis lonxe, o cantar que se considera máis antigo dos transmitidos polos cancioneiros é un sirventés político ${ }^{20}$. Esta vertente da lírica galego-portuguesa tivo que serlle familiar a Afonso ao menos desde os tempos da súa participación na guerra civil portuguesa. Este conflito estoupou co gallo da deposición de Sancho II e a designación do seu irmán Afonso, conde de Boulogne, como «protector do reino», decidida en 1245 polo Papa Inocencio IV a pedimento do episcopado portugués, coa complicidade de boa parte da nobreza. Destronado Sancho, o conde de Boulogne asumiría a coroa en 1248 -é o Afonso III O Bolonhês a que nos referimos atrás.

O noso Afonso, aínda infante, acudiu en apoio de Sancho II movido polo rexeitamento á inxerencia do Papado nun asunto político interno dun reino cristián (González Jiménez 1993: 22-24 e Mattoso 1987: 80-84). Recrutou un exército e penetrou en Portugal, pero finalmente tivo que se limitar a rescatar a Sancho para traelo ao exilio acompañado dun cortexo de nobres leais, moitos dos cales se converteron nos seus vasalos. Como consecuencia deste episodio varios dos trobadores portugueses desterrados instaláronse na corte afonsina e algúns deles convertéronse nos máis asiduos cultivadores da sátira política, como decontado veremos (Oliveira 2001: 113-122). Entre os nobres que acompañaron o infante na incursión en Portugal atopábanse trobadores galegos como Ayras Perez Vuytoron e xograres como Diego Pezello. Os cancioneiros recollen tres cantares ferozmente críticos con respecto á actuación do Bolonhês e os seus partidarios [Anexo n.ํ1, 2]. Nestas sátiras predominan dous temas que serán moi importantes no discurso satírico do noso Afonso: a deslealdade e a traizón ${ }^{21}$.

Ao longo das décadas seguintes non faltaron ocasións para que trobadores do seu séquito interviñesen a favor do soberano con motivo das súas desavinzas cos nobres. En total, non son menos de trinta as cantigas trobadorescas compostas na corte do Sabio que tocan directamente asuntos políticos, e máis dun terzo, concretamente once, foron compostas polo propio monarca ${ }^{22}$. Na súa maioría, trátase de cantigas de maldizer, o que significa que nelas a crítica é expresada de forma diáfana, mais entre elas hai tamén algunhas cantigas de escarnio ${ }^{23}$.

20 Trátase dunha cantiga composta polo trobador portugués Johan Soarez de Paiva con ocasión dun conflito na fronteira entre Navarra e Aragón, ocorrido por volta de 1196 (B 1330bis, V 937). Véxase Michaëlis 2004: 299-313 e López Aydillo 2008: 37-43.

21 O más brillante, sen dúbida, é a sátira de Ayras Perez Vuytoron (B 1477/V 1088). Véxase Michaëlis 1924, e Oliveira 1993a. Anos máis tarde, despois de vivir en carne propia rebelións contra el mesmo alentadas pola igrexa, Afonso lembrará a Sancho II nunha das composicións autobiográficas incluídas nas CSM:

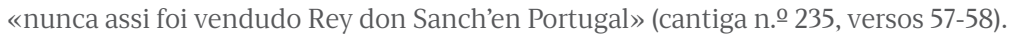

22 Alvar 1977: 181-258, especialmente 257-258.

23 A poética trobadoresca distinguía dous subxéneros de canción satírica: o escarnio e o maldizer. Nas cantigas de maldizer a crítica é expresada de forma ostensiva, directa e brutal. Ao contrario, a cantiga de escarnio disfraza o seu verdadeiro sentido mediante a aequivocatio, isto é, a ironía, a ambigüidade e o dobre sentido. As cantigas de escarnio cifran a súa mensaxe en chaves escuras, que esixen unha esexese especialmente enxeñosa (Liu 2004: 1-16). Afonso cultivou máis o maldizer ca o escarnio, mais outros trobadores da súa corte foron mestres requintados da aequivocatio, que adoito sementa de dúbidas calquera tentativa de interpretación (Lopes 1998: 103-117, 149-178; Alvar 1998: 7-8; Marcenaro 2010). 
O enfrontamento de Afonso co seu irmán Enrique, que se prolongou desde 1248 a 1258, deu azo para a composición dunha cantiga do propio rei (B 464) e dúas do portugués Gonçalo Eanes do Viñal que propalan a loia dos amores do príncipe coa súa madrasta, a raíña viúva Juana de Ponthieu [Anexo n.․ㅜ 12] ${ }^{24}$. Os enfrontamentos bélicos cos musulmáns na fronteira sur co gallo da revolta mudéxar (1263-1266), da incursión dos benimeríns (1275-1277) ou da campaña de represalia contra Granada (1280-81) motivaron a composición dunha serie de cantares de guerra en que Afonso fustriga da covardía dos coteifes que foxen ao primeiro embate e a deslealdade dos magnates que non acoden na súa axuda [Anexo n. 3, 4, 5, 6]. Os conflitos de Afonso coa Santa Sé, ben por culpa da frustración das súas aspiracións imperiais ou da lea que estalou ao redor da designación de arcebispo de Santiago (1266), están detrás da súa sátira contra o Papa [Anexo no 10]. Pola contra, o feito do imperio é obxecto dunha tenzón encomiástica entre Johan Vasquez de Talaveyra e Pedro Amigo de Sevilla [Anexo n. $\underline{0}$ 20].

A década dos setenta foi catastrófica para o monarca: revolta nobiliaria (1272), fin das aspiracións imperiais, invasión marinida, morte do infante Fernando de la Cerda (1275), preito sucesorio co futuro Sancho IV, execución do seu irmán Fadrique (1277)... Tres trobadores portugueses do seu cortexo dirixen as súas invectivas contra os magnates (ricos-homes) que se conxuraran contra o rei: Afonso Mendez de Besteyros [Anexo n.․ㅜ 10], Gil Perez Conde [Anexo n.ํㅗㅇ e Pero Gomez Barroso [Anexo n. 9$]^{25}$. A morte do infante don Manuel (1283), irmán menor do monarca e «príncipe dos traidores» que orquestraron a súa deposición en 1282 (Ballesteros 1984: 967), deu motivo para unha corrosiva sátira de Pero da Ponte [Anexo n.ํㅜ 13] ${ }^{26}$. A desolación da súa corte despois desta sucesión de desastres está expresivamente cantada nun texto de Gil Perez Conde [Anexo n.․ㅜ 18].

Este cantar suxire o ambiente depresivo en que un Afonso desenganado de vez puido compoñer os desconcertantes versos da inclasificable cantiga «Non me posso pagar tanto» [Anexo n.․19], en que vibra «com tons quase románticos o estado de espírito amargo de um protagonista decidido a abandonar o estado social privilexiado» (Bertolucci 1993: 39). Este «canto de desacougo» (Tavani 1986: 280), un dos máis célebres dos cancioneiros galego-portugueses, ten sido obxecto de interpretacións moi diversas, desde quen o le en termos autobiográficos ata quen, no extremo contrario, o considera un puro artificio, incluíndo quen pretende descifralo en chave onírica $^{27}$. Ao noso parecer, na cantiga o monarca expresa realmente os seus sentimen-

24 B1390/V999, V1008. Víñez 2004: 188-192 e 265-273; Lapa 1970: 64; Oliveira 2014: 14-15. Discútese o tema e a datación doutra cantiga de Afonso que podería estar relacionada co asunto: Lapa 1970: 65-67; Paredes 2010: 120-129; Mattoso 1985: 425-426; e Oliveira 2001: 118-119.

25 Véxase Beltrán 2007: 13-52. Este estudoso engade, ademais, unha composición de Pero da Ponte, «Mentre m’agora d'al non digo nada» (B1644, V 1178).

26 Lapa 1970: 549. A rúbrica da cantiga aclara:«Esta cantiga fez Pero da Ponte ao infante don Manuel».

27 Véxase Michaëlis 2004: 165-174; Lapa 1970: 13-16; Lanciani/Tavani 1995: 145-148; Lopes 1998: 170-173; Paredes 2001: 187-195, con remisión á bibliografía relevante; e Doubleday 2015: 178-179. 
tos, o cal resulta congruente co feito de que todos os seus outros cantares políticos teñen un contido manifestamente autobiográfico. Faino construíndo un artefacto literario preciosamente sofisticado, pero isto non lle resta sinceridade nin orixinalidade ao poema.

Do dito ata aquí pódense tirar tres conclusións. A sátira política é un dos motivos máis relevantes da produción trobadoresca de Afonso o Sabio e de varios trobadores da súa corte. Esta sátira é especialmente virulenta cando ataca os principais inimigos da política de reforzamento do poder real impulsada por Afonso con todo empeño. Está claro, pois, que o Rei Sabio non desdeñou colocar a lírica trobadoresca ao servizo dos seus intereses políticos. En definitiva, a política de Afonso con respecto á lírica trobadoresca galego-portuguesa foi coherente co seu proxecto global: ao converter a corte rexia no principal escenario daquela manifestación literaria, ao recoñecer aos xograres como trobadores, e ao involucrarse el mesmo como autor no movemento trobadoresco, o seu propósito era acabar co monopolio aristocrático sobre aquel fenómeno e aproveitar no seu beneficio o prestixio cultural de que gozaba. Vexamos se o proxecto de compilación das Cantigas de Santa María garda algunha relación con estes obxectivos.

\section{AFONSO O SABIO E AS CANTIGAS DE SANTA MARÍA, O SEU PROXECTO MÁIS PERSOAL}

O proxecto máis ambicioso de Afonso como cultivador da lírica en galego materializouse nas Cantigas de Santa María, unha das coleccións poético-musicais máis importantes da Idade Media europea. Esta magna obra foi composta seguindo «el método de producción de libros típicamente alfonsí, es decir, con la participación colectiva», isto é, «por una serie de equipos integrados y organizados en una «estructura de trabajo» que desarrolló una actividad de equipo controlada más o menos estrechamente por el rey» ${ }^{28}$. Con todo, un certo número de cantigas, especialmente as máis autobiográficas, foi atribuído á autoría persoal de Afonso. A xulgar polos códices sobreviventes, este magno proxecto materializouse en tres edicións diferentes, que en conxunto suman un total de 420 cantares $^{29}$.

A edición primitiva, probablemente encetada na segunda metade da década de 1250 e rematada antes de 1269, estaba composta de cen «cantares con sões

28 Monsalvo 2001: 224 e Martin 2001: 266. Véxase Martin 2001: 270-274 e Parkinson 2011: 83-85, 99. É tópico citar a explicación sobre o papel do monarca na elaboración das obras do seu taller que se ofrece na General Estoria: «El rey faze un libro non porque.l el escriva con sus manos, mas porque compone las razones d'el e las emienda, et yegua e enderesça, e muestra la manera de como se deve fazer, e des i escrivelas qui el manda, pero dezimos por esta razon que el rey faze el livro» (apud Martin 2001: 273).

29 Mettmann 1981: 28-31. Esta continúa sendo a edición de referencia do conxunto das CSM. 
saborosos», precedidos dunha «Intitulatio» non musicada que reivindica a autoría do monarca e un prólogo en que este lle ofrece o libro á Virxe e se declara o seu trobador, e seguidos dunha «Petiçon», a modo de epílogo, en que Afonso lle solicita a María que, como galardón pola súa ofrenda, interceda a prol do perdón dos seus pecados. Despois de confeccionado un primeiro códice, Afonso e o seu equipo continuaron axuntando milagres e compoñendo cancións e engadíronlle outras vinte e seis cantigas $^{30}$. Esta primeira colección foi transmitida nunha copia, códice To (Códice de Toledo), que é datada, dependendo dos estudosos, entre 1270 - data máis probable-e os inicios do século $\mathrm{XIV}^{31}$.

A edición máis ampla, probablemente iniciada na década de 1280 e acabada pouco antes do pasamento do monarca (1284), contén 415 cantares. Foi transmitida polo códice orixinal (E ou Códice dos Músicos), rematado dun xeito precipitado, talvez nos últimos meses de vida de Afonso, ou mesmo pouco despois do seu pasamento ${ }^{32}$. A edición de luxo, profusamente ilustrada, materializouse en dous tomos (Códice das Historias), dos cales só se completou o primeiro, con duascentas cantigas (T ou Códice Rico) 33. Stephen Parkinson, Martha Schaffer e Laura Fernández, entre outros, postulan que o Códice Rico representa unha edición inicialmente concibida como unha colección de 200 cantigas e que a súa duplicación se levaría a cabo mediante a produción dun novo volume, o Códice de Florencia. O feito de que o tomo que complementaría o Códice Rico, con duascentas cantigas máis, non chegase a ser finalizado (F ou Códice de Florencia), fai pensar que aínda se traballaba nel cando se produciu a morte do rei ${ }^{34}$.

Como sinala Martha Schaffer, as tres edicións deben ser contempladas «as at least three significantly «distinct works, each of them takes a predecessor version as a point of departure», ou sexa, como distinct phases in the life of a major literary or artistic project», no cal «each manuscript or version represents a particular perspective» (2000: 186-197). A redacción primitiva, representada polo Códice de Toledo, parece responder a un propósito fundamentalmente devocional: a elaboración dun libro de cantares á Virxe para uso persoal do monarca. A edición de luxo, Códice das Historias, estaría concibida non só para uso do soberano, senón que os seus dous volumes, ricamente iluminados, «deben ser entendidos en su dimensión

30 Monteagudo 2003: XI. Son cinco cancións das festas de Santa María, outras cinco de festas de Xesucristo, e dezaseis cantigas máis de milagres e loor. Ningunha destas composicións figura no índice da obra, copiado ao comezo, entre a Intitulatio e o Prólogo, o que é indicativo de que son engadidos posteriores.

31 Edición facsímile: Afonso X O Sabio, Cantigas de Santa María; transcrición en Afonso o Sabio 2010. Discusión deste punto e defensa da datación tardía con argumentos paleográficos e codicolóxicos en Fernández Fernández 2011: 47-53 y 72-78; e 2016/2017: 85-86, 114-117.

32 Ademais do prólogo e a «Intitulatio» recolle 400 cantigas (das que se repiten sete), a pitiçon, unha nova cantiga de loor e doce festas da Virxe, dúas das cales son repetición de cantigas de loor. Véxase Mettmann 1981: I, 28-31. Reprodución fotográfica en branco e negro: Alfonso X el Sabio 1964.

33 Edición facsímile: Alfonso X el Sabio 2011. Fernández Fernández 2011: 47-53 e 2016/2017: 92-93.

34 Edición facsímile: Alfonso X el Sabio 1989. Transcrición paleográfica en Fidalgo/F ernández 2019. 
plenamente cortesana, como parte del patrimonio librario de la Corona» (Fernández Fernández 2011: 51).

A edición completa, Códice dos Músicos, outorga unha especial relevancia aos aspectos melódicos e, de acordo co seu carácter musical, contén un repertorio icónico menos ostentoso. Fernández Fernández sostén que esta recompilación «no debe ser entendida como la culminación del proyecto, sino como un manuscrito que asegurase la perduración del cancionero completo, posiblemente motivado por la lentitud con la que se avanzaba en F » $^{35}$. Esta investigadora postula que este códice non se realizou con destino á corte, senón que foi pensado como unha peza de uso litúrxico para a Capela Real da Catedral de Sevilla, onde serviría á execución das cantigas durante as festas de santa María (Fernández Fernández 2011: 52-53).

Pola súa banda, Stephen Parkinson resume así a evolución do proxecto marial de Afonso:

The first collection begins as a personal mariale, a selection of mainly known pieces, and a personal act of devotion, inside troubadour culture [...] The increasing appreciation of the emblematic and exemplary function of a large collection of international and Iberian miracles, for political ends, emphasizing the monarch as the recipient of the favour of the Blessed Virgin who worked miracles throughout all the kingdoms of Iberia, leads to the consciously opulent outcome of the Códice de las Historias. (Parkinson 2011: 100)

A singularidade das Cantigas de Santa María dentro da oceánica obra afonsina foi destacada por unha pléiade de expertos. Así, Inés Fernández-Ordóñez chama a atención sobre o protagonismo outorgado ao rei como autor e actor tanto no texto coma nas imaxes dos códices iluminados, a un nivel que non ten parangón coas outras producións do obradoiro afonsino. Segundo esta investigadora, «las propiedades apotropaicas atribuidas al códice», «los tintes casi autobiográficos de texto e imagen», e o feito de que «el rey dispusiera su destino en forma testamentaria» manifestan a especialísima estima persoal que Afonso sentía por esta obra ${ }^{36}$. Por outra banda, esta mesma estudosa salienta tamén o parangón co conxunto da produción afonsina: a vontade autorial ao servizo dun proxecto político, o emprego exclusivo da lingua vulgar, o enciclopedismo didáctico e un afán de perfeccionamento constante, que produce varias versións da mesma obra. Movido pola súa insaciable curiosidade enciclopédica e un perfeccionismo enfermizo, o rei non deixaba de amorear información, de reformular os seus proxectos, de revisar e de reelaborar os textos para obter redaccións máis amplas e mellor acabadas, o que adoito provocou que algunhas ver-

35 Fernández Fernández 2016/2017: 105-106.

36 Fernández-Ordóñez 2011: 11-12; para as imaxes véxase Fernández Fernández 2011: 54-60. 
sións obras quedasen inconclusas ${ }^{37}$. Nese sentido, as CSM non son un caso illado, xa que se coñecen varias edicións, producidas baixo o seu mandato, dunha boa parte dos textos afonsinos.

\section{CANTIGAS, MILAGRES E SANTUARIOS NA POLÍTICA DE AFONSO}

Sen dúbida, a realización das CSM resultou custosísima, pois esixiu un xigantesco investimento de recursos financeiros, materiais e humanos (Schaffer 2000: 187). Alén dunha obvia motivación xenérica de «procura de prestixio e transcendencia», cómpre preguntarse polo sentido que Afonso imprimiu á súa empresa (Monsalvo 2001: 224). Antes de máis, semella claro que as CSM responden ás concepcións relixiosas do monarca. Neste sentido, a obra foi considerada a expresión de correntes renovadoras «orprendentemente avanzadas teológicamente y que, en algunos casos, rayaban la heterodoxia, o cuando menos, eran anti-conformistas con el pensamiento teológico tradicional» (Martínez 2003: 253). Concretamente, sinalouse que a colección se atopa imbuída dunha espiritualidade franciscana, que salienta a humanidade de Cristo e o papel da Virxe como co-redentora e mediadora.

Por outra banda, quíxose ver nas CSM unha manifestación artística «estrictamente civil», a plasmación dunha «visión laica de la cultura, aún en obras de alto contenido espiritual». Trataríase dunha espiritualidade vivida «al margen de las instituciones eclesiásticas»; de feito, «en las Cantigas Alfonso hace siempre de intermediario, sacerdote o maestro, entre María y el pueblo», papel que non se atribúe en ningún caso aos clérigos ${ }^{38}$. Nesta liña, Fernández-Ordóñez sinalou que «toda la concepción textual e iconográfica de las Cantigas minimiza el papel de la Iglesia y sus instituciones en la relación que los hombres establecen con la divinidad, en comparación con el ejercido por el rey» ${ }^{39}$. Por tanto, como di Georges Martin, nelas «es patente la voluntad de establecer una relación directa y personal del rey con el orbe espiritual que, apartando en cierto modo a la Iglesia, daba al monarca un papel destacado y casi sacerdotal» (Martin 2001: 284). Afonso preséntase como vicario de Deus, unha imaxe que reforzaba a autoridade do soberano no marco dunha nova ideoloxía do poder que resaltaba a hexemonía da monarquía (Doubleday 2005: 192).

Deste xeito, as interpretacións van esvarando das motivacións artísticas, sentimentais ou persoais de Afonso cara ao lugar das CSM no seu programa de goberno. En efecto, na liña apuntada polos xa citados Parkinson e Fernández-

37 Fernández-Ordóñez 2011: 13-14. Véxase también Martin 2001: 270-271.

38 Guerrero Lovillo, apud Martínez 2003: 248, 253.

39 Fernández Ordóñez 2011: 9. Para as imaxes, véxase Fernández Fernández 2011: 45. 
-Ordóñez, as CSM teñen sido consideradas un fiel reflexo non só da ideoloxía senón tamén do proxecto político do monarca. Jacques Le Goff chega a consideralas como «la plus grande entreprise d' exploitation politique du culte marial au Moyen Âge» (1990: 392), e para Martin, plasma a vontade de construír unha determinada imaxe pública do poder rexio e da súa persoa, o seu «yo tutelar y aglutinador», e constitúen «una auténtica proclamación política» (2001: 282 e 285). Igualmente, en consonancia co vasto programa científico e cultural emprendido por Afonso $\mathrm{X}$, tense subliñado que as CSM contribuirían á lexitimación sapiencial da realeza ${ }^{40}$. E, concretamente, as cantigas que narran milagres da Virxe que beneficiaban directamente a varios membros da familia real, nomeadamente a Fernando III e a súa dona a raíña Beatriz, foron relacionadas coa iniciativa de Afonso o Sabio de fundar unha capela real na catedral de Sevilla, a onde mandou trasladar os restos da súa nai e onde ergueu un mausoleo para o seu pai, establecendo un culto dinástico (Ferreira 2016: 307-308).

A colección marial de Afonso contén narracións amplamente difundidas en Europa e milagres relacionados con santuarios franceses que dispoñían das súas propias coleccións escritas, como Chartres, Soissons ou Rocamador. Por tanto, a súa realización requiriu un extenso traballo previo de documentación, materializado na recollida de numerosas fontes de todo tipo. Pero nas sucesivas edicións foron engadíronse relatos de milagres localizados en diversas rexións da Península, con especial predilección por Murcia e sobre todo por Andalucía, isto é, polos santuarios ergueitos e as poboacións fundadas polo propio Afonso nas terras que el mesmo conquistara. No total, inclúense máis de oitenta lendas marianas referidas a santuarios hispánicos, entre os cales o máis representado é o seu preferido, o Porto de Santa María, en Andalucía (24), seguido de Salas, en Aragón (22), Villasirga, na fronteira entre Castela e León (14), Terena, en Portugal (12) e Monserrat en Cataluña (6) ${ }^{41}$.

Desta maneira, as terras hispanas eran situadas na cartografía da ampla e prestixiosa tradición lírica mariana de modo a xerar «una tradición propia y autóctona» e así conseguir «una emancipación respecto de una tradición estándar» ${ }^{42}$. Neste sentido, tamén se contemplaron as CSM como «an attempt to promote the territorial power of Christianity in the newly conquered territories of western Andalusia» (Doubleday 2005: 190), isto é, «como parte del engranaje de recuperación y consolidación del territorio llevado a cabo por la Corona» (Fernández Fernández 2011: 45). Esta é a liña de interpretación que adopta Elvira Fidalgo, ao defender que a preeminencia outorgada aos santuarios marianos do sur da península, na nova España cristiá, obedecería ao «deseo del monarca de llamar la atención» sobre eses territorios, disputados cos musulmáns nuns casos, e con Portugal noutros. Canto á importancia dada a unha serie santuarios do norte, como Salas, Monserrat e sobre todo Villasirga, esta

40 Martin 2001: 273-274; Fernández-Ordóñez 2011: 8-9; Ayala Martínez 2011: 22.

41 Procter 2002: 39-43; Snow 2016/2017: 67-82; Fidalgo 2005: 157-170.

42 Monsalvo 2001: 224. Véxase tamén Martin 2001: 284. 
estudosa considera que a intención era promocionalos para que fixesen competencia á antiga, prestixiosa e aínda nutrida peregrinación a Compostela.

O obxectivo sería «desviar el importante flujo de peregrinos que iban a Santiago», ben para reforzar os centros de peregrinación do norte, ben para «aumentar el entusiasmo popular por las nuevas iglesias» do sur, «para repoblar nuevos territorios y crear nuevos asentamientos de población cristiana ${ }^{43}$. O problema desta caste de interpretacións, é que, como lembra Martin, «las Cantigas fueron destinadas al público de corte» (2001: 285). Concretamente, Kennedy suxire que o Códice Rico puido estar destinado a unha capela restrinxida para os membros da Orden de Santa María de España, creada polo rei, mentres que o Códice dos Músicos estaría destinado a un público cortesán máis amplo. En todo caso, «Alphonso’s intended readers were the courtiers and clerics who surrounded him», e as súas eran «works that present royal ideology to a literate, élite section of society, not to wider population» (Kennedy 2019: 28, 44, 151 e 218), e se nesta, como observa Ferreira, incluso tiveron unha recepción limitada, non se diga fóra dela (Ferreira 2016: 297-301 e 309-320; Kleine 2013: 30-36 refírese tamén á dificultade de comprensión por razón da lingua, Ferreira 2016: 324 descarta que existise tal dificultade). Por tanto, non puideron chegar, nin sequera en forma de afastado eco, a ese suposto público popular que debía dirixirse a aqueles santuarios favorecidos polo monarca. Esa limitación non é contraditoria co feito de que «the collection reflects an ambitious political and religious agenda, and that it was designed at the outset to have aural public impact both within and beyond the court», como acertadamente sinala Ferreira (2016: 320).

\section{A PEREGRINACIÓN XACOBEA NAS CANTIGAS. A LEA DO ARCEBISPADO DE SANTIAGO}

Sexa como for, é innegable que nas CSM latexa unha intención de parte de Afonso de «contra-programar» a peregrinación a Compostela, ou polo menos de eclipsar a celebridade deste santuario, enxalzando outros cultos rivais. Esta intención maniféstase de forma tanto implícita como explícita. En sete cantigas en que se fai referencia á peregrinación xacobea ou á cidade de Santiago, a mención do santuario do apóstolo brilla pola súa ausencia, e o mesmo acontece coas composicións localizadas en Galicia, que son unicamente sete, unha cifra moi baixa en comparanza con outras terras peninsulares ${ }^{44}$. Por exemplo, na cantiga $n^{\underline{0}} 184$ relátanse milagres

43 Fidalgo 2005: 170-176. As citas son das páxinas 172-173 e 176.

44 Procter 2002: 41; Fidalgo 2005: 154-156; Pousada 2010: 513-522. As cantigas localizadas en Galicia

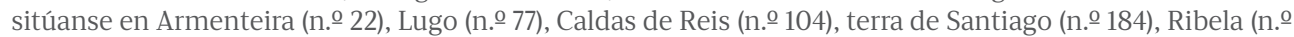
304), O Monte (n. 317) e O Viso (n. $\underline{3}$ 35). A cantiga n.. 103, que narra o milagre do monxe que botou trescentos anos escoitando o cantar do paxariño, non está situada explicitamente en Armenteira. 
de María na propia terra de Santiago, mentres que dous milagres que no Liber Sancti Jacobi son atribuídos ao Apóstolo en beneficio de cadanseu peregrino a Compostela, nas CSM son asignados á Virxe María, outorgando ao apóstolo un papel secundario (n. $\underline{0} 26$ e ก. $\underline{0} 175)$.

Pero noutras cantigas, como observa Fidalgo, máis valera o silencio ca a mala propaganda. Na cantiga no 218 , un peregrino alemán chega a Compostela pero non é curado por Santiago, senón pola Virxe de Villasirga na súa viaxe de volta. Noutra cantiga, a Virxe venerada neste mesmo santuario levántalle a penitencia a un romeu a Compostela (n. ㅇ 253). Á vista disto, non é de estrañar que na cantiga no 268 uns «romeus que de Santiago ían» aconsellasen a unha fidalga francesa que camiñaba en peregrinación a Compostela que se desviase do camiño para ir a Villasirga. A dona seguiu o consello e alí foi curada. Con estes antecedentes, tampouco sorprende que, segundo relata a cantiga n. $\underline{2} 278$, outra fidalga que viña curada da súa cegueira grazas á Virxe de Villasirga recomendase a un romeu que se dirixía a Santiago que se desviase a este santuario, polo visto máis milagreiro ca o apóstolo.

A publicidade negativa da peregrinación xacobea nas CSM ten sido obxecto de diversas lecturas. Para a maioría, a antipatía do rei é manifesta, ata o punto de falarse de «contra-propaganda»; só Montoya, sen moitos argumentos, refuga este tipo interpretacións como «gratuítas» (1991: 93). Un motivo da animadversión anti-santiaguista de Afonso que parece obvio é o seu prolongado litixio coa igrexa de Santiago. Desde os inicios do seu reinado, o monarca viuse obrigado a intervir en «muchos pleytos et demandas et querelas et contiendas» entre o clero catedralicio (arcebispo e cabido) e o concello. López Ferreiro tratou destas desavinzas, por suposto analizándoas desde unha posición favorable á igrexa, e apunta que «el astuto D. Alfonso X se aprovechó [...] para ingerirse en el señorío de la ciudad y nombrar Alcalde del Rey [...] Así iba D. Alfonso X preparando el terreno para dar el golpe á que le impulsaban los burgueses compostelanos ${ }^{45}$.

No medio dun clima de desconfianza do monarca cara ao Papado por causa do feito do Imperio, e no marco da súa política de afirmación do poder real, á morte do arcebispo Xoán Airas (1266), Afonso quixo impor como arcebispo de Compostela o cóengo Xoán Afonso, membro da familia real, pois era fillo bastardo do seu avó Afonso (López Ferreiro 1902: 227-232). O cabido compostelán dividiuse en dous bandos, a Santa Sé non aceptou o candidato proposto polo soberano e a prelatura quedou vouga ata 1267 , mentres o soberano se proclamaba protector de Santiago. Coa súa complicidade, os burgueses, en gráfica expresión de López Ferreiro, «se envalentonaron» e quixeron tomar as rendas da cidade. Nestas, o Papa designou arcebispo ao mitrado de Coimbra, Egas Fafez, quen, para complicar as cousas, finou antes de tomar pose. 
Entrementres, o Papado tamén quedaba vougo polo falecemento do Papa Clemente IV (1268), ata a proclamación de Gregorio X (1272). Así que sentou na cadeira de san Pedro, o novo Papa coutou de vez aspiracións imperiais de Afonso e pretendeu designar un arcebispo sen o acordo do rei (1273). Porén, en palabras de López Ferreiro, «alentados los burgueses compostelanos por la actitud más que equívoca del Rey D. Alfonso X, se negaron a reconocerlo por su Señor», mentres que o monarca lle esixía que lle prestase homenaxe (obriga que nunca tivera un arcebispo compostelán), se apropiaba da Pertiguería maior da terra de Santiago, tentaba privalo dos privilexios sobre os portos da diocese e se apoderaba das fortalezas nas terras da súa xurisdición. Finalmente, para fuxir da ira rexia, o arcebispo tivo que se exiliar, como fixeron moitos membros do cabido compostelán (López Ferreiro 1902: 239-248; véxase tamén o artigo de Francisco Hernández neste mesmo volume). Poida que o ambiente empezoñado destas encirradas liortas fose suficiente para explicar o nada disimulado anti-santiaguismo que destilan as Cantigas de Santa María.

\section{DISCUSIÓN E CONCLUSIÓNS: POR QUE TROBOU AFONSO O SABIO EN GALEGO?}

E con isto chegamos á cuestión da lingua. Visto o visto, non deixa de chocar que Afonso o Sabio escollese compoñer as CSM en galego, sendo unha obra que responde a motivacións, toca asuntos e ten propósitos alleos a Galicia e os galegos. Tense dito que o uso do romance en detrimento do latín, vinculado á orientación secularizadora do seu programa cultural fronte ao monopolio eclesiástico da cultura escrita, respondía a unha intención didáctica, isto é, ao desexo difundir determinados saberes ou de transmitir certas mensaxes nunha lingua comprensible a un público non alatinado: «o seu programa intelectual é didáctico e persegue o valor pedagóxico da utilidade inmediata» (Ayala Martínez 2011: 39). Mais este argumento non é suficiente para explicar o uso do galego nas CSM. Para Fernández-Ordóñez, as razóns disto foron máis ben de orde política:

Si toda la construcción política de Alfonso el Sabio propone a la monarquía castellano-leonesa como legítima aspirante al imperium peninsular, no hay que olvidar que ese edificio se levantaba tanto sobre el reino de Castilla como sobre el de León [...] En el paradigma cultural alfonsí el castellano como lengua de la cultura escrita en Castilla se flanquea del gallego como lengua de León, relevante testimonio de la voluntad integradora de la pluralidad lingüística de sus dominios. (2011: 12) 
Monsalvo Antón postula que Afonso tentou outorgar ao galego «en el marco protonacional del reino castellano-leonés» un papel de lingua cultural reservada á poesía lírica, comparable ao que o provenzal ocupaba entón no conxunto do arco mediterráneo. Por tanto, segundo este estudoso, o uso do galego nas cantigas afonsinas debe entenderse «en contraposición con el provenzal, como afirmación de una dignidad propiamente hispánica, y desde luego no en contraposición al castellano» (2001: 264).

Alén das anteriores interpretacións, non debe esquecerse a explicación defendida desde hai tempo por algúns estudosos. Afonso atopouse cunha situación na cal, desde un par de xeracións anteriores á súa, no centro e occidente da península, o cultivo do xénero lírico estaba asociado ao romance galego, grazas ao temperán impulso que lle deran algunhas familias da nobreza galaica. Isto dotárao duns recursos que os romances veciños tardarían en acadar. Formulouno con precisión Gerold Hilty ao sinalar que «Galicia se adelantó a Castilla en la creación del género de poesía amorosa y de escarnio en romance y, una vez constituido tal género, Castilla lo adoptó»; xa que o galego, sendo a lingua dun dos seus reinos, «se comprendía y ofrecía formas literarias que se podían aprovechar para la expresión de la lírica amatoria y sarcástica». Como advirte este estudoso, «no podemos enfocar esta situación desde una perspectiva moderna (nacionalista y regionalista) ni desde la perspectiva de la filología románica, que tiene que considerar el castellano y el galaico-portugués como dos lenguas románicas autónomas y distintas» (Hilty 2002). Por tanto, como sinala Ferreira, «Alfonso’s minstrels were expected to sing in Galician-Portuguese irrespective of the listener's mother tongue» (2016: 324).

En efecto, como xa salientara Tavani, ata os séculos XIII- XIV en varias áreas culturais de Europa, desde a Inglaterra anglo-normanda, ata Italia e a España cristiá, conviviron diversas tradicións literarias en réxime de simbiose. Nelas existiu unha asociación entre determinadas variedades lingüísticas e certos xéneros literarios análoga á que existía en toda Europa occidental entre os idiomas vulgares e o latín. Alleas á idea de unificación lingüística do territorio dun estado ao redor dun estándar nacional, as distintas tradicións literarias que xeraran cadansúa koiné para un xénero concreto (lírica, épica, narrativa) eran concibidas como mutuamente complementarias. Xa que logo, o galego-portugués non debe considerarse «a lingua poética dunha escola nacional, nin era considerada dun xeito tan restritivo por parte dos que a usaban», senón que, pola contra, asumiu a «función de vehículo expresivo dun xénero poético cultivado, degustado, imitado en toda a península centro-occidental, nun réxime de civilización literaria común» (Tavani 1986: 33-36).

O devandito é indubidable para a lírica trobadoresca profana. Canto ás CSM, aínda se pode argumentar dun xeito máis concreto. Davide Romano sinalou que para realizar as súas obras de «de sçiencias e de saberes», Afonso tivo que recorrer a persoal capacitado, que para o caso eran sabios xudeus especialistas nas materias 
tratadas e competentes en árabe e castelán, pero non en latín (Romano 1990: 682-695, Doubleday 2015: 62-64). Ora, para a realización das CSM cumpría dispor dun nutrido equipo de trobadores expertos cun completo dominio da gaya sciencia (Ferreira 2016: 320-323). Para tal, os artesáns que estaban ao alcance de Afonso eran na súa inmensa maioría galegos, capaces de aplicar ao seu idioma complexas técnicas compositivas como o cómputo silábico coas súas requintadas pautas e licenzas métricas, as regras da rima e da estrofa... O galego xa fora exercitado para estes mesteres, dispuña dun rico léxico e da necesaria flexibilidade sintáctica (Filgueira 1980: 1415). Non debe ser casualidade que o único nome que chegou a nós de colaboradores poéticos das CSM sexa o do clérigo e trobador compostelán Ayras Nunez (Mettmann 1971). Velaí unha serie de razóns, de carácter técnico e puramente práctico, para o uso do galego na composición das CSM.

Finalmente, á hora de xulgar a contribución de Afonso ao lirismo trobadoresco galego-portugués convén ter en conta a cautela expresada por Simon Doubleday (2005: 190) contra a «temptation to empathise excessively with courtly culture, and with a remarkably cultured king, in a way that distorts our understanding». Así, non pode deixar de verse na empresa mariana un propósito de reorientación da lírica galego-portuguesa en favor dun proxecto estritamente persoal do monarca. En certa maneira, tratouse dunha operación de expropiación dun patrimonio inmaterial - o capital simbólico adquirido polo galego- que viña sendo detido preferentemente pola nobreza galego-portuguesa e, subsidiariamente, pola nobreza leonesa e castelá. Conforme a opinión de José C. Miranda,

não é a língua que o leva para junto daqueles que a exercitavam, mas o contrário: é a necessidade [...] de estabelecer relações estreitas com o mundo senhorial do ocidente peninsular que leva Afonso a tornar-se trovador e, mais tarde, no seio do mundo trovadoresco, a procurar, pela palavra e pela acção, tornar-se a voz de comando desse mesmo mundo [...] o projecto de Afonso X no tocante ao galego-português e à sua quase exclusiva expressão trovadoresca revelou ser uma subtil operação de apropriação e de transfiguração monárquica de uma linguagem essencialmente vassálica e aristocrática, operação realizada ao longo de décadas. (Miranda 2012: 17)

Isto canxa perfectamente co empeño de Afonso por centralizar os saberes ao redor da coroa en canto tiña que ver coa «organización de su producción, al impulso económico que recibieron, al lugar que se les dio en la construcción del poder regio y de su imagen» (Martin 2001: 285). Mais, por outra banda, como subliña o mesmo estudoso, «tal vez la constante iniciativa cultural del rey haya debilitado en alguna medida la producción cultural fuera de la corte y de los talleres regios» (ibidem). É moi 
probable que o seu afán centralizador minguase a vitalidade da lírica trobadoresca galego-portuguesa, especialmente en terras galegas. Aquí, durante o reinado de Afonso, a lírica continuaba viva da man de humildes, pero soberbios, xograres, como Martin Codax e Mendiño, mais o certo é que a partir da década de 1280 practicamente non houbo remuda xeracional, e non se rexistran trobadores galegos activos despois dos primeiros anos dos século XIV. De 1300 ata 1350, só as cortes de don Denis e do seu fillo bastardo Pedro Afonso, Conde de Barcelos, darían acollida, ao sur do Miño, a unha manifestación cultural en constante refluxo (Tavani 264-273; Oliveira 1995: 79-86).

Así, o balance da súa achega á cultura expresada en lingua galega é mixto. A súa corte foi un escenario privilexiado para a lírica trobadoresca, que atraeu un importante grupo de trobadores e xograres. O monarca recoñeceu o estatuto artístico dos segundos, poñendo fin ao monopolio nobiliar desta manifestación cultural. Probablemente, promoveu a compilación do primeiro cancioneiro xeral da lírica trobadoresca galego-portuguesa, o arquetipo da tradición manuscrita sobrevivente. Neste cancioneiro acolleu non soamente as cantigas dos cabaleiros, como acontecera nas recollas previas, senón tamén dalgúns segreis e clérigos. Porén, os xograres continuaron excluídos del, e a súa incorporación ao ramo principal da tradición manuscrita tivo que agardar varias décadas, ata a confección dunha nova compilación xeral, hipoteticamente por iniciativa de don Denis (Monteagudo 2019: 932-951).

Canto ás Cantigas de Santa María, por moito que hoxe nos marabillemos pola súa opulencia e a súa calidade artística, e por moito que as estimemos como un testemuño sen par das artes, a cultura e a sociedade do seu tempo, a verdade é que acabaron por resultar un proxecto tan grandioso na súa concepción e espléndido na súa realización como estéril nos seus efectos (Filgueira 1985: 48-49; Tavani 1986: 58; Ferreira 2016: 297-298, 333-340). En definitiva, Afonso o Sabio foi un xenio paradoxal, foino en si e para si e foino tamén para Galicia, o seu idioma e a súa cultura. 


\section{REFERENCIAS BIBLIOGRÁFICAS}

- Afonso X o Sabio (2008): Cantigas de Santa Maria. Edición facsímile do Códice de Toledo (To). Biblioteca Nacional de Madrid (Ms 10.096), Santiago de Compostela, Consello da Cultura Galega.

- Afonso X o Sabio (2010): Cantigas de Santa Maria, Códice de Toledo (Transcrición de Marta Schaffer), Santiago de Compostela, Consello da Cultura Galega.

- Alfonso el Sabio (1964): La música de las Cantigas de Santa María de Alfonso el Sabio. I. Facsímil del códice j.b.2 de El Escorial, Barcelona, Diputación Provincial 7 Biblioteca Central.

- Alfonso X el Sabio (1989): Cantigas de Santa María. Tomo I. Edición facsímil del códice B.R. 20 de la Biblioteca Nazionale Centrale de Florencia: siglo XIII, Madrid, Edilán.

- Alfonso X el Sabio (2011): Las Cantigas de Santa María: Códice Rico, Ms. T-I-1, Real Biblioteca del Monasterio de San Lorenzo de El Escorial. Tomo I. Edición facsímil, Madrid, Patrimonio Nacional/Testimonio.

- Alvar, Carlos (1977): La poesía trovadoresca en España y Portugal, Madrid, Cupsa.

- Alvar, Carlos (1978): Textos trovadorescos sobre España y Portugal, Madrid, Cupsa.

- Alvar, Carlos (1984): «Poesía y política en la corte alfonsí», Cuadernos Hispano-Americanos, 410, 5-20.

- Alvar, Carlos (1985): «La cruzada de Jaén y la poesía gallego-portuguesa», en Vicente Beltrán (ed.), Actas del I Congreso de la Asociación Hispánica de Literatura Medieval, Barcelona, Promociones y Publicaciones Universitarias, 139-144.

- Alvar, Carlos (1986): «Las poesías de Pedro García de Ambroa», Studi Mediolatini e Volgari, 32, 11-40.

- Alvar, Carlos (1998): «Alfonso X, poeta profano. Temas poéticos. La corte poética del Rey», en Anton Touber (ed.), Le Rayonement des Troubadours, Actes du colloque de l'AIEO, Amsterdam/Atlanta, Rodopi, 3-17.

- Ayala Martínez, Carlos (2011): «El reinado de Alfonso X: la síntesis de una época», en Laura Fernández Fernández/Juan C. Ruiz Souza (eds.), Alfonso X el Sabio. Las Cantigas de Santa Maria. Códice Rico Ms T-I-1, Madrid, Patrimonio Nacional/ Testimonio, vol. 2, 17-42.

- Ballesteros Bereta, Antonio (1984): Alfonso X el Sabio, Barcelona, El Albir.

- Beltrán, Vicente (1993): «Pedr’Amigo de Sevilha», en Giulia Lanciani/Giuseppe Tavani (eds.), Dicionário da Literatura Medieval Galega e Portuguesa, Lisboa, Caminho, 519-520.

- BeLtRÁN, Vicente (2005): La corte de Babel. Lenguas, poética y política en la España del siglo XIII, Madrid, Gredos. 
- Beltrán, Vicente (2007): Poética, poesía y sociedad en la lírica medieval, Santiago de Compostela, Universidade.

- Bertoluci, Valeria (1993): «Alfonso X», en Giulia Lanciani/Giuseppe Tavani (eds.), Dicionário da Literatura Medieval Galega e Portuguesa, Lisboa, Caminho, 36-41.

- Brandẽo, António (1974): Monarquia Lusitana. Parte Quarta, Lisboa, Imprensa Nacional/Casa da Moeda.

- Couceiro, José L. (1993): «Pero d’Armea», en Giulia Lanciani/Giuseppe Tavani (eds.), Dicionário da Literatura Medieval Galega e Portuguesa, Lisboa, Caminho, 536-537.

- Deyermond, Alan D. (1981): Historia de la literatura española. 1. La Edad Media, Barcelona, Seix Barral.

- Doubleday, Simon (2005): «O que foi passar a serra: Frontier-crossing and the thirteenth-century nobility in the cantigas de escarnio e maldizer», en Martin Aurell (ed.), Le médiéviste et la monographie familiale: sources, méthodes et problematiques, Turnhout, Brepols, 189-200.

- Doubleday, Simon (2015): The Wise King. A Christian Prince, Muslim Spain, and the Birth of the Renaissance, New York, Basic Books.

- FALCÃo, Fernanda Scopel (2019): O trobar do segrel Lourenço nas tenções galego-portuguesas: uma retórica da impertinência. Tese de doutoramento inédita. Vitória, Universidade Federal do Espírito Santo.

- FALCÃo, Fernanda Scopel (2019): «Segréis, jograis-trovadores, doctores de trovar: especialização do ofício jogralesco e da convenção trovadoresca em solo ibérico», Roda da Fortuna, 8:1, 60-76.

- FERnÁndez FERnÁndEz, Laura (2011): «Este livro, com’achei, fez á onr'e á loor da Virgen Santa Maria: El proyecto de las Cantigas de Santa Maria en el marco del escritorio regio. Estado de la cuestión y nuevas reflexiones», en Laura Fernández Fernández/Juan C. Ruiz Souza (eds.), Alfonso X el Sabio. Las Cantigas de Santa Maria. Códice Rico Ms T-I-1, Madrid, Patrimonio Nacional/Testimonio, vol. 2, 43-78.

- FERnÁndez FERnÁndez, Laura (2016/2017): «Los manuscritos de las Cantigas de Santa María: definición material de un proyecto regio», Alcanate, X, 81-117.

- FERnÁndEZ-ORdóñEz, Inés (2011): «Prólogo. Las Cantigas de Santa María en el marco de las producciones alfonsíes: semejanzas y diferencias», en Laura Fernández Fernández/Juan C. Ruiz Souza (eds.), Alfonso X el Sabio. Las Cantigas de Santa Maria. Códice Rico Ms T-I-1, Madrid, Patrimonio Nacional/Testimonio Compañía Editorial, vol. 2, 7-15.

- FERNÁNDEZ-ORDÓÑEZ, Inés (2013): «Alfonso el Sabio en la historia del español», en Rafael Cano (ed.), Historia de la lengua española, Barcelona, Planeta, 381-422. 
- FerReira, Maria do Rosário (2012): «As traduções de castelhano para galego-português e as políticas da língua nos séculos XIII-XIV», e-Spania [En liña], consultado o 21 marzo de 2017. URL: http://e-spania.revues.org/21021; DOI: 10.4000/e-spania.21021.

- Ferreira, Manuel Pedro (2016): «The Medieval Fate of the Cantigas de Santa Maria: Iberian Politics Meets Song», Journal of the American Musicological Society, 69:2, 295-353.

- Fidalgo Francisco, Elvira (2005): «Peregrinación y política en las Cantigas de Santa Maria», en Elvira Fidalgo (ed.), Formas narrrativas breves en la Edad Media. Actas del IV Congreso, Santiago de Compostela, Universidade, 149-179.

- Fidalgo Francisco, Elvira/Fernández Guiadanes, Antonio (2019): O Códice de Florencia das Cantigas de Santa Maria (B.R. 20). Transcrición paleográfica, Santiago de Compostela, Xunta de Galicia.

- Filgueira Valverde, Xosé F. (1980): Afonso X e Galicia e unha escolma de cantigas, A Coruña, Real Academia Galega.

- Filgueira Valverde, Xosé F. (1985): «Introducción», en Alfonso X el Sabio, Cantigas de Santa María, Madrid, Castalia, 1985, XI-LXIII.

- Gonçalves, Elsa (2016): De Roma ata Lixboa. Estudos sobre os cancioneiros galego-portugueses, A Coruña, Real Academia Galega.

- GonZÁlez JiméneZ, Manuel (1993): Alfonso X el Sabio, 1252-1284, Palencia, La Olmeda.

- Hilty, Gerold (2002): «El plurilingüismo en la corte de Alfonso X el Sabio», en María T. Echenique Elizondo/Juan Sánchez Méndez (eds.), Actas del V Congreso Internacional de Historia de la Lengua Española. Vol. I, Madrid, Gredos, 207-220.

- KLeINE, Marina (2013): «El carácter propagandístico de las obras de Alfonso X», De Medio Aevo, 4:2, 1-42.

- Lanciani, Giulia/TaVani, Giuseppe (1995): As cantigas de escarnio, Vigo, Xerais.

- LaPa, Manuel Rodrigues (1970): Cantigas d'escarnho e de maldizer dos cancioneiros medievais galego-portugueses, Vigo, Galaxia.

- LAPESA, Rafael (1981): Historia de la lengua española, Madrid, Gredos.

- Le Goff, Jacques (1990): «Le roi, la Vierge et les images: le manuscrit des Cantigas de Santa Maria d'Alphonse X de Castille», en Paul de Clerk/Eric Palazzo (eds.), Rituels: Mélanges offerts à Pierre-Marie Gy, O.P., Paris, Cerf, 385-392.

- Liu, Benjamin (2004): Medieval Joke Poetry. The «Cantigas d'Escarnho e de Mal Dizer», Cambridge (Massachusetts)/London, Harvard University Department of Comparative Literature. 
- LOPES, Graça Videira (1998): A sátira nos cancioneiros galego-portugueses, Lisboa, Estampa.

- LÓPEZ AydiLlo, Eugenio (2008): Los cancioneros gallego-portugueses como fuentes históricas, Valladolid, Maxtor.

- López Ferreiro, Antonio (1902): Historia de la Santa A. M. Iglesia de Santiago de Compostela. Tomo V, Santiago, Imprenta del Seminario Conciliar Central.

- López FERreiro, Antonio (1975): Fueros municipales de Santiago y de su tierra, Madrid, Ediciones Castilla.

- Lorenzo VÁzQuez, Ramón (1993): «Pero da Ponte», en Giulia Lanciani/Giuseppe Tavani (eds.), Dicionário da Literatura Medieval Galega e Portuguesa, Lisboa, Caminho, 537-539.

- Marcenaro, Simone (2010): L'equivocatio nella lirica galego-portoghese medievale, Alessandria, Edizioni dell'Orso.

- Márquez Villanueva, Francisco (1995): El concepto cultural alfonsí, Madrid, Fundación MAPFRE América.

- Marroni, Giovanna (1968): «Le poesie di Pedr'Amigo de Sevilha», Annali dell' Istituto Universitario Orientale. Sezione Romanza, 10, 189-339.

- MARTin, George (2001): «Los intelectuales y la corona: la obra histórica», en Manuel Rodríguez Llopis (ed.), Alfonso X y su época. El siglo del rey sabio, Barcelona, Carroggio, 259-286.

- Martínez, H. Salvador (2003): Alfonso X, el Sabio. Una biografía, Madrid, Polifemo.

- Mattoso, José (1985): Portugal Medieval. Novas interpretações, Lisboa, Imprensa Nacional/Casa da Moeda.

- Mattoso, José (1987): Fragmentos de uma composição medieval, Lisboa, Estampa.

- MenÉndez Pidal, Ramón (1924): Poesía juglaresca y juglares. Aspectos de la historia literaria y cultural de España, Madrid, Junta para la Ampliación de Estudios e Investigaciones Históricas/Centro de Estudios Históricos.

- Mettmann, Walter (1981): «Introdução», en Afonso X O Sábio, Cantigas de Santar Maria, Vigo, Xerais, vol. I, 16-36.

- Mettmann, Walter (1971): «Airas Nunes, Mitautor der “Cantigas de Santa Maria”», Iberorromania, 3, 8-10.

- Michä̈LIS DE VASCONCELlOS, Carolina (1924): «Em volta de Sancho II», Lusitânia, 2, 7-25.

- Michä̈lis de VAsconcellos, Carolina (1990): Cancioneiro da Ajuda. Reimpressão da edição de Halle (1904), acrescentada de um prefacio de Ivo Castro e do glossário das cantigas (Revista Lusitana, XXIII), 2 vols., Lisboa, Imprensa Nacional/Casa da Moeda. 
- MichaËLIs de Vasconcellos, Carolina (2004): Glosas marginais ao cancioneiro medieval portugués de Carolina Michaëlis de Vasconcelos, Coimbra, Universidade.

- Miranda, José C. (2004): Aurs mesclatz ab argen. Sobre a primeira geração de trovadores galego-portugueses, Porto, Guarecer.

- Miranda,JoséC. Ribeiro (2012): «Ogalego-portuguêse os seus detentores aolongo do século XIII», e-Spania [en liña], consultado o 21 de marzo 2021. URL: http://journals. openedition.org/e-spania/21084; DOI: https://doi.org/10.4000/e-spania.21084.

- Monsalvo AnTÓN, José M. (2001): «Renacimiento cultural y progreso científico en el ámbito europeo», en Manuel Rodríguez Llopis (ed.), Alfonso X y su época. El siglo del rey sabio, Barcelona, Carroggio, 195-234.

- Montoya Martínez, Jesús (1991): O cancioneiro marial de Afonso X, o Sabio, Santiago de Compostela, Universidade.

- Monteagudo, Henrique (2003): «Cantares con sões saborosos de cantar. Apuntamentos para un proemio», en Afonso X O Sabio, Cantigas de Santa Maria. Edición facsímile do Códice de Toledo (To), Santiago de Compostela, Consello da Cultura Galega, VII-XIII.

- Monteagudo, Henrique (2008): Letras primeiras. O foral do Burgo de Caldelas, os primordios da lírica trovadoresca e a emerxencia do galego escrito, A Coruña, Fundación Pedro Barrié de la Maza.

- Monteagudo, Henrique (2014): A nobreza miñota e a lírica trobadoresca na Galicia da primeira metade do século XIII: a personalidade histórica do trobador Johan Soayrez Somesso, os trobadores Afonso Soarez Sarraça e Estevan Fayan, Noia, Toxosoutos.

- Monteagudo, Henrique (2019): «Variación scriptolingüística e tradición manuscrita da lírica trobadoresca: As variables $<\mathrm{nh} / \mathrm{n}>\mathrm{e}<\mathrm{ss} / \mathrm{s}>$ », en Ernestina Carrilho/ Ana Maria Martins/Sandra Pereira/João Paulo Silvestre (eds.), Estudos lingüísticos e filológicos oferecidos a Ivo Castro, Lisboa, Centro de Lingüística da Universidade de Lisboa, 859-960.

- Oliveira, António Resende de (1987): «A cultura trovadoresca no Ocidente peninsular: trovadores e jograis galegos», Biblos, 63, 1-22.

- Oliveira, António Resende de (1989): «A Galiza e a cultura trovadoresca», Revista de História das Ideias, 11, 7-36.

- OliveIRA, António Resende de (1993a): «Airas Perez Vuitoron», en Giulia Lanciani/ Giuseppe Tavani (eds.), Dicionário da Literatura Medieval Galega e Portuguesa, Lisboa, Caminho, 28-29.

- Oliveira, António Resende de (1993b): «Segrel», en Giulia Lanciani/Giuseppe Tavani (eds.), Dicionário da Literatura Medieval Galega e Portuguesa, Lisboa, Caminho, 609-611. 
- Oliveira, António Resende de (1994): Depois do espectáculo trovadoresco. A estrutura dos cancioneiros peninsulares e as recolhas dos séculos XIII e XIV, Lisboa, Colibri.

- Oliveira, António Resende de (1995): Trobadores e xograres. Contexto histórico, Vigo, Xerais.

- Oliveira, António Resende de (1998): «Galicia trobadoresca», Anuario de Estudios Literarios Galegos, 207-229.

- Oliveira, António Resende de (2001): O trovador galego-português e o seu mundo, Lisboa, Editorial Notícias.

- Oliveira, António Resende de (2009): «Distracções e cultura», en Leontina Ventura, D. Afonso III, [S.l.], Círculo de Leitores, 270-317.

- Oliveira, António Resende de (2010a): «D. Afonso X, infante e trovador. I. Coordenadas de uma ligação à Galiza», Revista de Literatura Medieval, 22, 257-270.

- Oliveira, António Resende de (2010b): «D. Afonso X, infante e trovador. II. A produção trovadoresca», La parola del testo, 14, 7-19.

- Oliveira, António Resende de (2010c): «Na casa de Afonso X. O rei, a corte e os trovadores (abordagem preliminar)», Revista de História das Ideas, 31, 53-76.

- Oliveira, António Resende de (2013): «O Irrequieto Cancioneiro Profano do Rei Sábio», Revista Portuguesa de História, 44, 257-277.

- Oliveira, António Resende de (2014):. «A produção trovadoresca de Afonso X: 3. Os cantares de guerra», Revista de História das Ideas, 31, 9-29.

- Oliveira, António Resende de (2015): «A produção trovadoresca de Afonso X. 2. Entre trovadores e jograis galego-portugueses», La corónica, 43:2, 5-27.

- Oliveira, A. Resende de/José C. Miranda (1995): «A segunda geração de trovadores galego-portugueses: temas, formas, realidades», en Juan Paredes (ed.), Medioevo y literatura. Actas del V Congreso de la Asociación Hispánica Medieval, Granada, Universidad, vol. 3, 499-512.

- Oliveira, A. Resende de/José C. Miranda (1998): «Le surgissement de la culture troubadouresque dans l'Occident de la Péninsule ibérique (I). Compositeurs et cours», en Anton Touber (ed.), Le Rayonement des Troubadours, Actes du colloque de l'AIEO, Amsterdam/Atlata, Rodopi, 85-95.

- Paredes, Juan (2010): El cancionero profano de Alfonso X el Sabio, Santiago de Compostela, Universidade.

- Parkinson, Stephen (2011): «Alfonso X, miracle collector», en Laura Fernández Fernández/Juan C. Ruiz Souza (eds.), Alfonso X el Sabio. Las Cantigas de Santa Maria. Códice Rico Ms T-I-1, Madrid, Patrimonio Nacional/Testimonio Compañía Editorial, vol. 2, 79-100. 
- Pousada Cruz, Miguel A. (2010): «A contrapropaganda do Camiño de Santiago nas Cantigas de Santa María», en Esther Corral (ed.), In Marsupiis Peregrinorum. Circulación de textos e imágenes alrededor del Camino de Santiago en la Edad Media. Actas del Congreso Internacional, Firenze, Edizioni del Galluzzo, 509-525.

- Procter, Evelyn S. (2002): Alfonso X de Castilla, patrono de las letras y el saber, Murcia, Real Academia Alfonso X el Sabio.

- Río GRANDE, María G. del (2018): «Alacrán negro nen veiro». Simbología, metáfora y textualidad del escorpión en los textos alfonsíes», Letras, 78, 127-140.

- Rodríguez Velasco, Jesús D. (1999): Castigos para celosos, consejos para juglares, Madrid, Gredos.

- Romano, Davide (1990): «Le opere scientifiche di Alfonso X e l'intervento degli ebrei», en Oriente e Occidente nel Medioevo. Filosofia e scienze. Convegno Internazionale, 9-15 aprile 1969, Roma, Accademia Nazionale dei Lincei, 677-711.

- SCHAFFer, Martha (2000): «The Evolution of the Cantigas de Santa Maria: The Relationships between Manuscripts T, F and E», en Stephen Parkinson (ed.), Cobras e Son. Papers on the Text Music and Manuscripts of the Cantigas de Santa Maria, Oxford, Legenda, 186-213.

- SNOw, Joseph T. (2016/2017): «La utilización política de la devoción mariana en el reinado de Alfonso X, el Sabio (1252-1284)», Alcanate, X, 61-85.

- Souto Cabo, José A. (2006): «Pedro Garcia de Ambroa e Pedro de Ambroa», Revista de Literatura Medieval, 18, 225-248.

- Souto CABo, José A. (2011a): «A emergência da lírica galego-portuguesa e os primeiros trovadores», A Trabe de Ouro, 87, 367-392.

- Souto Cabo, José A. (2011b): «Lopo Lias: entre Orzelhão e Compostela», Diacrítica, 25, 109-133.

- Souto Cabo, José A. (2012a): Os cavaleiros que fizeram as cantigas. Aproximação às origens socioculturais da lírica galego-portuguesa, Niteroi, Universidade Federal Fluminense.

- Souto Cabo, José A. (2012b): «En Santiago, seend’ albergado en mia pousada. Nótulas trovadorescas compostelanas», Verba, 39, 273-298.

- Souto Cabo, José António/Vieira, Yara Frateschi (2003): «Para um novo enquadramento histórico-literário de Airas Fernandes, dito 'Carpancho'», Revista de Literatura Medieval, 16, 221-277.

- TAVANI, Giuseppe (1986): A poesía lírica galego-portuguesa, Vigo, Galaxia.

- Tavani, Giuseppe (1993): «Sátira política», en Giulia Lanciani/Giuseppe Tavani (eds.), Dicionário da Literatura Medieval Galega e Portuguesa, Lisboa, Caminho, 608-609. 
- Ventura, Joaquim (2014): «A trindade de Pedro Garcia de Ambroa», Revista de Cancioneros, Impresos y Manuscritos, 3, 181-231.

- VIEIRA, Yara Frateschi (1999): En cas dona Maior. Os trovadores e a corte senhorial galega do século XIII, Santiago de Compostela, Laiovento.

- Vieira, Yara Frateschi/Isabel Morán Cabanas/José A. Souto Cabo (2012): O amor que eu levei de Santiago. Roteiro da lírica medieval galego-portuguesa, Noia, Toxosoutos.

- VíñEz SÁNCHEZ, Antonia (2004): El trovador Gonçal’Eanes Dovinhal. Estudio histórico y edición, Santiago de Compostela, Universidade. 



\section{ANEXO}

Cantigas satíricas de Afonso o Sabio e o seu círculo 

A seguir ofrécese unha escolma satíricas de cantigas de Afonso o Sabio e outros trobadores do seu séquito, con dúas modestas pretensións: acompañar o artigo, ofrecendo unha ilustración máis ampla dalgunhas das observacións que nel se conteñen, e ofrecer unha mostra da produción satírica de Afonso, enfocada cara aos temas considerados no dito artigo. A edición que se ofrece non ten outras pretensións que as divulgativas, aínda que non por iso está exenta de rigor filolóxico. Moitos dos textos presentan problemas de lectura moi difíciles. Tentamos resolvelos, mais, dado o propósito da edición, non nos detemos a ofrecer explicacións das solucións que adoptamos. As notas que acompañan non teñen máis finalidade que contextualizar os textos e facilitar a súa lectura. Por vía da regra, tomamos como referencia as lecturas que se ofrecen no projeto littera, a que remitimos para maiores explicacións e esclarecementos ${ }^{1}$. O glosario do espazo web Universo Cantigas dá precisa información sobre o significado concreto de cada termo².

\section{CRITERIOS DE EDICIÓN}

En xeral, respectouse a materialidade gráfica dos textos, pero aplicáronselles algunhas intervencións para facilitar a lectura:

Modernizouse a puntuación, a unión se separación de palabras e o uso de minúsculas e maiúsculas. As formas clíticas como os pronomes átonos aparecen separadas da palabra antecedente mediante un trazo: chorar-lh'-ey, querrey-vo-lh' eu, alhu-lo demandade, poi-lo ben faço, vende-la galdrapa.

Non se impuxeron acentos gráficos, salvo con valor diacrítico: é (verbo) / e (conxunción), én (pronome) / en (preposición).

Introducíronse distincións gráficas entre as vogais e consoantes $<\mathrm{u}>/<\mathrm{v}\rangle \mathrm{e}<\mathrm{i}\rangle /<\mathrm{j}\rangle \mathrm{e}$

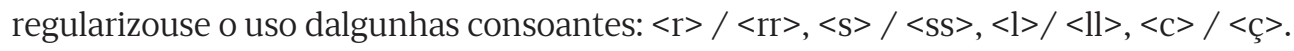
En posición final, xeneralizouse a grafía $<$ n $>$ para a consoante nasal.

$\mathrm{O}<\mathrm{h}>$ eliminouse cando non ten motivación etimolóxica ( $h u n>$ un), repúxose cando a ten (herdar, hoste, home), excepto no verbo aver e no adverbio e conxunción ora, e regularizouse para os pronomes medievais hy e $h u$ (estes últimos non levan $<$ h-> nas Cantigas de Santa María).

Regularizouse o uso de $<y>$ seguindo o criterio de frecuencia: úsase cando vai en ditongo en final de palabra (vay, rey, foy, muy), na secuencia -eyro / -eyra, cando representa a vogal tónica dun hiato (aynda, Raynha) e en familias léxicas ou variantes do mesmo vocábulo (rey / reyno, muy / muyto). Nas Cantigas de Santa María reprodúcense as grafías $<\mathrm{y}>/<\mathrm{i}>$ do códice.

1 Lopes, Graça Videira / Manuel Pedro Ferreira et alii (2011-): Cantigas medievais Galego Portuguesas. http://cantigas.fcsh.unl.pt

2 Ferreiro, Manuel (dir.) (2018-): Universo Cantigas. Edición crítica da poesía medieval galego-portuguesa, Universidade da Coruña. http://universocantigas.gal 
Todas as composicións de carácter satírico veñen transmitidas polos apógrafos italianos, copiados dunha compilación realizada en Portugal, polo que se emprega sistematicamente as grafías $<\mathrm{lh}>\mathrm{e}<\mathrm{nh}>$. Nas Cantigas de Santa María as grafías correspondentes son $<$ ll $>$ e $<$ nn $>$ ou $<\tilde{n}>$.

As palabras ou letras restituídas ou corrixidas van entre corchetes [ ], salvo nos caso dos refráns. Nas Cantigas de Santa María, o refrán non é reproducido despois de cada estrofa.

\section{O SIRVENTÉS POLÍTICO. CANTARES DE BATALLA I.1. A GUERRA CIVIL PORTUGUESA (1246-1248)}

\section{AYRAS PEREZ VUYTORON (B1477, V1088)}

Esta outra cantiga é de maldizer dos que deron os castelos como non devian al Rey don Afonso.

A lealdade de Bezerra, que pela Beyra muyto anda, ben é que a jur a tenhamos, pois que no-lo Papa manda.

Non ten Sueyro Bezerra que tort' é en vender Monsanto, ca diz que nunca Deus diss' a san Pedro mais de tanto: «Quem tu legares en terra erit ligatum in celo»; poren diz ca non é torto de vender hom'o castelo.

E poren diz que non fez torto o que vendeu Marialva, ca lhe diss' o arcebispo un vesso per que se salva: «Estote fortes in bello et pugnate cum serpente», poren diz que non é torto quen faz traiçon e mente.

O que vendeu Leyrea muyto ten que fez dereito, ca fez mandado do Papa e confirmou-lh' o esleito «Super istud caput meum et super ista mea capa» dade o castelo ao Conde, pois vo-lo manda o Papa.

O que vendeu Faria por remiir seus pecados, se mais tevesse, mais daria; e disseron dous prelados: «Tu autem, Domine, dimitte» aquel que se cofonde; ben esmolou en sa vida quen deu Santaren ao Conde.

Ofereçeu Martin Diaz aa cruz, que os cofonde, Covilhãa, e Pero Diaz Sortelha; e diss' o Conde: 
«Centuplum accipiatis» de mão do Padre Sancto.

Diz Fernan Diaz: «Ben m’est[e], por que oferi Monsanto».

[Pois non] ofereçeu Trancoso ao Conde Roy Bezerro, falou enton don Soeyro por sacar seu filho d' erro:

«Non potest filia mea sine patre suo facere quidquam»:

salvos son os traedores, pois ben hisopados fican!

O que ofereceu Sintra fez come bon cavaleyro, e disso-lhi o legado log'un vesso do Salteyro:

«Sagitte potentis acute», e foy hy ben acordado:

melhor é de seer traedor ca morrer escomungado.

E quando o Conde ao castelo chegou de Celorico, Pachec' enton o cuitelo tirou; et disse-lh'un bispo: «Mitte gladium in vagina», con el non nos empeescas.

Diz Pacheco: «Alhur, Conde, peede hu vos digam: Crescas!».

Maldisse don Ayras Soga ũa velha noutro dia; disse-lhi Pero Soarez un vesso per clerizia:

«Non vetula bombatricon scandit confusio ficum»; non foy Soeyro Bezerra alcaide de Celorico.

Salvos son os traedores quantos os castelos deron; mostraron-lhi en escrito [que foy ben quanto fezeron] «super ignem eternum et divinitatis opem»: salvo é quen trae castelo, a preito que o hisopen!

\section{Comentario}

Unha das sátiras máis célebres dos cancioneiros, datable por volta de 1247. Refírese a feitos históricos, censurando a traizón dos tenentes dun conxunto de castelos do centro de Portugal (a Beira), que foron entregados ao Conde de Bolonha (o «rey don Afonso» a que se refire a rúbrica explicativa), traizoando ao monarca lexítimo, Sancho II, e coa beizón do Papa e os bispos. Ayras Perez Vuytoron foi un cabaleiro galego que seguramente participou na hoste convocada polo infante Afonso para ir en axuda de Sancho II contra os rebeldes. A entrega do castelo de Monsanto por parte de Sueyro Bezerra é tomada como paradigma da deslealdade. En cada estrofa menciónase un ou dous castelos rendidos a traizón: Monsanto, Marialba, Leiria, Faria, Covilhãa, Sortelha, Trancoso, Sintra, Celorico. O Papa e os bispos encirraran a revolta nobiliar contra Sancho e beiceron a súa deposición, de xeito que a complicidade do clero cos revoltados exprésase na cantiga con cadanseu verso latino (ou macarrónico) por estrofa, en moitos casos citando versículos bíblicos ou frases dos oficios do ritual católico. 


\section{Notas}

ben é que a jur a tenhamos: é xusto que a consideremos de lei (legal)

418 Non ten Sueyro Bezerra que tort'é en vender Monsanto: Non pensa S. B. que hai delito en vender Monsanto «Quem tu legares en terra erit ligatum in celo»: «O que ti atares na terra será atado no ceo» poren diz ca non é torto de vender hom'o castelo: por tanto, di que non é delito vender o castelo ca lhe diss' o arcebispo un vesso per que se salva: xa que o arcebispo lle recitou un versículo que o salva «Estote fortes in bello et pugnate cum serpente»: «Sede fortes na batalla e loitade coa serpente» confirmou-lh' o esleito: confirmoullo o (bispo) elexido «Super istud caput meum et super ista mea capa»: «Sobre a miña cabeza e sobre a miña capa» remiir: redimir

«Tu autem, Domine, dimitte» aquel que se cofonde: «Ti, Señor, perdoa» aquel que se perde «Centuplum accipiatis»: «Recibideres o céntuplo» «Non potest filia mea sine patre suo facere quidquam»: «Non pode a miña filla facer nada sen o pai» hisopados: bendicidos e disso-lhi o legado log'un vesso do Salteyro: e díxolle o enviado do papa un verso do Libro dos Salmos «Sagitte potentis acute»: «Frechas potentes e afiadas» «Mitte gladium in vagina», con el non nos empeescas: «Mete a espada na vaíña, con el non nos incomodes Diz Pacheco: «Alhur, Conde, peede hu vos digam: Crescas!»: verso de difícil lectura e escura interpretación «Non vetula bombatricon scandit confusio ficum»: verso de difícil lectura e escura interpretación «super ignem eternum et divinitatis opem»: «por riba do lume eterno e do poder divino» salvo é quen trae castelo, a preito que o hisopen!: salvado queda o que traizoa o castelo, con tal de que o bendigan!

\section{DIEGO PEZELHO, JOGRAR (B1592, V1124)}

Meu Senhor arcebispo, and' eu escomungado

porque fiz lealdade: enganou-mi o pecado.

Soltade-m', ay Senhor,

e jurarey, mandado, que seja traedor.

Se traiçon fezesse nunca vo-la diria;

mais, pois fiz lealdade, vel por Santa Maria,

soltade-m', ay, Senhor,

e jurarey, mandado,

que seja traedor.

Per mia malaventura tivi ũu castelo en Sousa

e dey-o a seu don' e tenho que fiz gran cousa:

soltade-m', ay, senhor,

e jurarey, mandado,

que seja traedor.

Per meus negros pecados tive ũu castelo forte e dey-o a seu don' e ey medo da morte. 
soltade-m', ay, senhor,

e jurarey, mandado,

que seja traedor.

\section{Comentario}

Outra sátira, cargada de ironía, centrada nos mesmos feitos ca a anterior, e novamente poñendo en foco non só os traidores que entregaron os castelos, senón tamén a xerarquía eclesiástica que encirrou a rebelión dos nobres. A cantiga está posta en boca dun tenente leal ao rei (fixen lealdade, tiven un castelo en Sousa e deillo ao seu dono) que confesa o seu «pecado» (se traizón fixese, non me confesaría) e pide absolución ao arcebispo de Braga (soltade-me), xurando que se corrixirá e será un traidor. Diego Pezello é un xograr, probablemente galego e tal vez empregado de Airas Perez Vuitoron, que acompañou a hoste do infante Afonso na súa incursión en Portugal.

\section{I.2. AS CAMPAÑAS EN AL-ANDALUS}

\section{AFONSO O SABIO (B472)}

Pero que ey ora mengua de conpanha, nen Pero Garcia nen Pero d' Espanha

nen Pero Galego

non irá comego.

E ben vo-lo juro par Santa Maria:

que Pero d' Espanha nen Pero Garcia

nen Pero Galego

non iran cõmego.

Nunca cinga espada con bõa baynha,

se Pero d' Espanha nen Pero Galinha

nen Pero Galego

for ora cõmego.

Galego, Galego, outren irá comego!

\section{Comentario}

Primeira da serie de cantigas de Afonso contra os nobres que refugaron acompañalo coas súas hostes nas campañas militares en Andalucía, ben co gallo da revolta mudéxar de 1264 ou ben nas campañas da década seguinte. A acusación refírese xeneri- 
camente aos nobres galegos e «de Espanha», empregado o nome «Pero» (Pedro) nun sentido xeral, e deslizando unha acusación de covardía (Pero Galinha).

\section{Notas}

Pero que ey ora mengua de conpanha: Aínda que peciso reforzos. outren irá comego!: outro irá comigo!

\section{AFONSO X O SABIO (B491, V74)}

O genete

pois remete

seu alfaraz corredor:

estremece

e esmorece

o coteife con pavor.

Vi coteifes orpelados

estar muy mal espantados,

e genetes trosquiados

corrian-nos arredor;

tiinhan-nos mal aficados,

[e] perdian-na color.

Vi coteifes de gran brio

eno meyo do estio

estar tremendo sen frio

ant' os mouros d' Azamor;

e ia-se deles rio

que Auguadalquivir mayor.

Vi eu de coteifes azes

con infanções siguazes

muy peores ca rapazes;

e ouveron tal pavor

que os seus panos d' arrazes

tornaron doutra color.

Vi coteifes con arminhos, conhocedores de vinhos, que rapazes dos martinhos, que non tragian Senhor, 
saíron aos mesquinhos,

e fezeron todo peor.

Vi coteifes e cochões

con muy longos granhões

que as barvas dos cabrões:

ao son do atanbor

os deitavan dos arções

ant' os pees de seu Senhor.

\section{Comentario}

Vibrante sátira que fustiga a covardía dos coteifes (cabaleiros viláns) ante a cabalaría inimiga, os temibles genetes (da cabalería bereber), que cruzaron o Estreito de Xibraltar en auxilio do rei de Granada.

\section{Notas}

alfaraz: corcel árabe.

coteifes orpelados: soldados barbados?

genetes trosquiados: soldados rapados.

mal aficados: moi apertados.

Azamor: cidade da costa marroquina.

e ia-se deles rio...: íaselles un río maior ca do Guadalquivir, isto é, mexaban por eles (de terror).

infanções siguazes: cabaleiros nobres que ía detrás (?).

que os seus panos d' arrazes /...: os seus panos de Arrás quedaron sen cor (do medo).

conhocedores de vinhos: referencia escura difícil de interpretar.

rapazes dos martinhos: referencia escura.

con muy longos granhões: con longas greñas.

\section{AFONSO X O SABIO (B494, V77)}

O que foy passar a serra

e non quis servir a terra,

é ora, entrant' a guerra,

que faroneja?

Pois el agora tan muyto erra,

maldito seja!

O que levou os dinheyros

e non troux' os cavaleyros,

é por non ir nos primeyros

que faroneja? 
Pois que ven cõn-os prostumeyros,

maldito seja!

O que filhou gran soldada

e nunca fez cavalgada,

é por non ir a Graada

que faroneja?

Se é ricomẽ ou á mesnada,

maldito seja!

O que meteu na taleiga

pouc' aver e muyta meiga,

é por non entrar na Veiga

que faroneja?

Pois chus mol[e] é que manteiga,

maldito seja!

\section{Comentario}

Outra cantiga contra a falta de apoio dos nobres nas campañas bélicas do rei en Andalucía. Probablemente, neste caso refírese a un personaxe que o seu auditorio recoñecería, ou talvez a catro personaxes (un por estrofa) que serían notorios na época. Simon Doubleday propón datar a cantiga en 1274ca. e identificar o personaxe con Nuno Gonzalez de Lara, compañeiro desde a mocidade, do círculo de maior confianza do rei, que en 1271-72 liderou a rebelión dos nobres e buscou refuxio no reino de Granada (foy passar a serra). Os nobres, que nesa ocasión se aliaron co rei de Granada, entre outras cousas, reclamaban o pagamento dos seus servizos (soldada). A cantiga tamén podería referirse á campaña de represalia contra o rei de Granada de 1278, pola súa complicidade coa incursión dos benimeríns, e de aí a referencia á «Veiga» (de Granada). A chave da cantiga está no verbo faronejar, «quedar atrás, avanzar lentamente, con desidia». O verbo probablemente é derivado do adxectivo farón, aplicado ao animal (cabalo, burro,... ) que se nega a andar.

\section{Notas}

é ora, entrant' a guerra, / que faroneja?: é agora, cando comeza a guerra, cando queda atrás?

o que meteu na taleiga / ... o que meteu na alforxa pouco haber e moito conto.

Pois chus mole é que manteiga: pois é máis brando ca a manteiga (alusión á covardía). 
6. AFONSO O SABIO (B496/144b, V79)

Quen da guerra levou cavaleyros

e a sa terra foy guardar dinheyros,

non ven al mayo.

Quen de guerra se foy con maldade

e a sa terra foy comprar herdade,

non ven al mayo.

O que da guerra se foy con nemiga

pero non veo quand' é preitesia,

non ven al mayo.

O que tragia o pano de linho

pero non vẽo polo San Martinho,

non ven al mayo.

O que tragia o pendon sen cinco

e [e]no dedo sen pedra o vinco,

non ven al mayo.

O que tragia o pendon sen oyto

e a sa gente non dava pan coyto,

non ven al mayo.

O que tragia o pendon sen sete

e cinta ancha e muy gran topete,

non ven al mayo.

O que tragia o pendon sen tenda, per quant' agora sey de sa fazenda,

non ven al mayo.

O que con medo se foy dos martinhos

e a sa terra foy bever los vinhos,

non ven al mayo.

O que con medo fugiu da fronteyra

pero tragia pendon sen caldeyra,

non ven al mayo.

O que roub[ava] os mouros malditos

e a sa terra foi roubar cabritos,

non ven al mayo.

O que da guerra se foy con espanto

e a sa terra ar foy armar manto,

non ven al mayo.

O que da guerra se foy con gran medo

contra sa terra, espargendo vedo,

non ven al mayo. 
O que tragia pendon de cadarço, macar non vẽo en mes de março, non ven al mayo.

O que da guerra [se] foy recreudo, macar en Burgos fez pintar escudo, non ven al mayo.

\section{Comentario}

Outra cantiga máis da serie satírica contra os nobres que non acoden coas súas hostes ás campañas militares do rei en Andalucía. A chave aquí está no refrán, que fai referencia á convocatorias de reunión das tropas, que adoitaban realizarse no mes de maio, cando se iniciaba a temporada propicia para as hostilidades.

\section{Notas}

O que tragia o pendon sen cinco /...: o que traía o estandarte, pero sen nin tan sequera cinco combatentes, e no dedo o anel sen pedra (enténdase coma unha comparanza).

e a sa gente non dava pan coyto: e á súa hoste non lle daba pan cocido.

e cinta ancha e muy gran topete: modo de axeitar o cabelo da parte superior da cabeza típico dos nobres rurais. O que con medo se foy dos martinhos: o que se foi con medo dos combatentes mouros (?)

Pero tragia pendon sen caldeyra: o pendón sen a insignia que demostraba capacidade dos cabaleiros para contribuír cos seus medios á guerra.

contra sa terra, espargendo vedo: para a súa terra, morto de medo (escagarriado).

cadarço: seda basta.

recreudo: covarde.

macar en Burgos fez pintar escudo: probable alusión ás cortes de Burgos de 1272, onde os nobres impuxeron as súas demandas ao rei.

\section{AFONSO MENDEZ DE BESTEYROS (B1558)}

Don Foão, que eu sey que á preço de livão, vedes que fez ena guerra -daquesto soo certão: sol que viu os genetes, come boy que fer tavão, sacudiu-se e revolveu-se, alçou rab' e foy sa via a Portugal.

Don Foão, que eu sey que á preço de ligeyro, vedes que fez ena guerra -daquesto son verdadeyro: sol que viu os genetes, come bezerro tenreyro, sacudiu-se e revolveu-se, alçou rab’ e foy sa via a Portugal. 
Don Foão, que eu sey que á prez de liveldade, vedes que fezo na guerra - sabede-o por verdade: sol que viu os genetes, come can que sal de grade,

sacudiu-se e revolveu-se, al-

çou rab' e foy sa via a Portugal.

\section{Comentario}

Outra sátira máis contra a covardía dos nobres nas guerras andaluzas, neste caso dirixida a un nobre portugués, que non aparece identificado (don foão: «un tipo»). Afonso Mendez de Besteyros foi un cabaleiro portugués, partidario do deposto rei Sancho II; que ou ben se exiliou a Castela con Afonso o Sabio, ou ben estivo na súa corte.

\section{Notas}

á preço de livão / de ligeyro // prez de liveldade: ten sona de covarde. sol que viu os genetes: nada máis ver os xinetes (cabaleiros bereberes). come boy que fer tavão, / ...: como un boi picado por un tabán, ... alzou o rabo e liscou para Portugal. come can que sal de grade: coma o can que sae da gaiola.

\section{GIL PEREZ CONDE (B1516)}

Non troux' estes cavaleyros aqui este ricome nunca na guerra, que ora trage; son doutra terra, ca ja eu [en eles] mentes meti; nen seus numes non-os conhosco, ca lhis dissera «bon dia vosco!», mais nẽhun [deles] eu non conhoci.

Nen estas armas eu nunca lhas vi trajer na guerra, destes sinaes que ora trage non trouxe taes nosco na guerra quand' el Rey foy hy, nen outras; por que as ar faria, senon quae-las ante tragia? E ja sobr' esto con muytos departi.

Nen el enton non parecia assy na guerra, cordo como parece, ca nen cavalgada nen ensandece nunca fezeron en que el non foss' y; 
e as lazeyras per que passava, andand[o] aló, tan pouco dava por elas come se nunca foss' [y].

Nen custa nunca a receava; nen perda, nen med', alá hu andava... nunca de tal home falar oý.

\section{Comentario}

Gil Perez Conde é un cabaleiro portugués que estivo nas cortes de Afonso o Sabio e Sancho IV, autor dunha sobranceira obra satírica. Esta sátira hai que interpretala en chave irónica: o trobador marabíllase coa presenza dun nobre e a súa hoste, que se presentan cando non fan falla, pois non hai guerra, pero non acudiron cando era preciso ao campo de batalla.

\section{PERO GOMEZ BARROSO (B1443, V1054)}

Un ricome que oj' eu sey, que na guerra non foy aqui, ven muy sanhudo e diz assi como vos agora direy:

diz que ten terra qual pediu, mais, porque a nunca serviu, á muy gran querela del Rey. El vẽo, se Deus mi pardon, des que viu que era paz; ben lhi venha [hy], se ben faz, pero mostra el tal razon:

diz que ten terra qual pediu, mais, porque a nunca serviu, contra el Rey anda muy felon.

Pero na guerra non fez ben nen mal, que non quis hy viir con coyta del Rey non servir, pero mostra el ũa ren:

diz que ten terra qual pediu, mais, porque a nunca serviu, al Rey quer muy gran mal poren. 
Sanhudo ven contr' el Rey ja,

ca, hu foy mester, non chegou,

e mais de mil vezes jurou

que da terra non sairá;

diz que ten terra qual pediu,

mais, porque nunca a serviu,

al Rey poren gran mal querrá.

\section{Comentario}

Outra sátira anti-nobiliar dun trobador portugués exilado na corte afonsina despois da guerra civil portuguesa. De feito, participou na conquista de Sevilla e gañou un notable peso político ao lado de Afonso o Sabio, que lle encargou unha delicada misión negociadora como intermediario entre o monarca e os nobres revoltados contra el en alianza co rei de Granada, nun dos momentos máis criticos do reinado de Afonso. A cantiga, en chave de irónica paradoxa, censura un aristócrata (ricome) que non se presentou a auxiliar o monarca na guerra e despois preséntase enfadado (sanhudo), alegando que o rei lle concedeu a terra que el pedira e vén a queixárselle, porque non a serviu como debera.

\section{Notas}

que na guerra non foy aqui: que non se presentou cando a guerra.

ven muy sanhudo: vén moi airado.

El vẽo ... desque viu que era paz: presentouse cando chegou a paz.

ben lhi venha [hy], se ben faz / ...: que lle preste, se lle convén.

con coyta del Rey non servir: con afán de non servir ao Rei.

pero mostra el ũa ren: explica el o seguinte.

ca, hu foy mester, non chegou: porque, cando era necesario, non se presentou.

\section{DESAVINZAS CO PAPA E SÁTIRA DO CLERO}

10. AFONSO O SABIO (B463)

Se me graça fezesse este Papa de Roma!

Pois que er os panos da mia reposte toma,

que levass' el os cabos e dess' a mí a soma;

mais doutra guisa me foy el vende-la galdrapa.

Quisera eu assy ora deste nosso Papa

que me talhasse melhor aquesta capa. 
Se m’ el graça fezesse con os seus cardeaes, que lh' eu dess' e que mos talhasse iguaes; mais vedes en que vi en el maos sinaes, que do que me furtou, foy cobri-la sa capa.

Quisera eu assy ora deste nosso Papa

que me talhasse melhor aquesta capa.

Se con os cardeaes, con que faz seus conselhos, posesse que guardasse nós de maos trebelhos, fezera gran mercee, ca non furtar con elhos e os panos dos cristãos meter sô sa capa.

Quisera eu assy ora deste nosso Papa

que me talhasse melhor aquesta capa.

\section{Comentario}

Sátira do monarca contra o Papa, censurándoo porque lle rouba dereitos e bens que lle pertencen. A partir desta interpretación xeral da cantiga, que é bastante clara, a chave para a interpretación do seu texto concreto, bastante escuro para o lector actual, está no significado dos panos e da capa e todo o xogo cos duplos significados destes termos e doutros relacionados con eles, incluíndo frases feitas de significado que intuímos pero pouco claro para nós (vende-la galdrapa, talhar iguaes, talhar ũa capa, cobri-la sa capa, meter sô sa capa). Os panos fan referencia ás teas en xeral e ás vestimentas en particular. Son bastantes as cantigas satíricas que se refiren aos panos nos dous sentidos: por unha parte, como medio de pagamento (pois como tales eran usados naquel tempo), por outra parte, xogando cos distintos tipos de vestimenta como expresión do status social. Seguindo isto, probablemente co pano de fondo da disputa sobre a coroa imperial, a que Afonso aspirou e o Papa acabou por negar (1272), coñécese que na Afonso acusa o Papa de apropiarse de haberes ou dereitos que lle corresponden como monarca (talvez aludindo tamén á designación dos bispos, cuestión candente polo conflito sobre o arcebispado de Compostela), e mesmo de apropiarse de bens de todos os cristiáns, quizais aludindo aos tributo que cobraba a Igrexa e que en parte eran desviados a Roma.

\section{Notas}

Pois que er os panos da mia reposte toma / ...: visto que as roupas do meu vestiario colle que levass' el os cabos e dess' a mí a soma: que quedase el coas pezas de menor valor e me deixase a min as mellores

doutra guisa me foy el vende-la galdrapa: doutro xeito me vendeu el o pano; a galdrapa era un manto que se colocaba na garupa da cabalgadura, debaixo da sela de montar; a expresión empregada parece ten un sentido de «enganar».

que me talhasse melhor aquesta capa: que me cortase mellor esta capa; que me arranxase mellor este negocio 
que lh' eu dess' e que mos talhasse iguaaes: que eu llos dese e mos cortase polo mesmo padrón; o sentido pode ser «que aceptase os prelados da miña preferencia»

mais vedes en que vi en el maos sinaes / ...: mais reparade en que eu notei os seus maos modos, as súas avesas intencións.

que do que me furtou, foy cobri-la sa capa: que foi cubrir a súa capa do que me furtou; o sentido pode ser «que se foi vestir co que me roubou», «que se aproveitou ou alardeou do que me quitou» (a coroa imperial?).

posesse que guardasse nós de maos trebelhos: se dedicasen a protexernos de maos pasos

ca non furtar con elhos /...: e non roubar con eles (os cardeais) e meter os bens dos cristiáns nos seus petos (sô sa capa).

\section{AFONSO X O SABIO (B493, V76)}

Ao dayan de Calez eu achei livros que lhi levavan de Berger; e o que os tragia preguntey por eles, e respondeu-m’ el: «Senher, con estes livros que vós veedes dous e con-os outros que ele ten dos sous, fod' el per eles quanto foder quer.

E aynda vos end' eu mais direy: macar na Ley muyt'á leer [mester], por quanto eu [de] sa fazenda sey, con-os livros que ten, non á molher a que non faça que semelhen grous os corvos, e as aguias babous, per força de foder, se x' el quiser.

Ca non á mais, na arte do foder, do que nos livros que el ten jaz; e el á tal sabor de os leer, que nunca noite nen dia al faz; e sabe d' arte do foder tan ben, que con-os seus livros d' artes, que el ten, fod' el as mouras cada que lhi praz.

E mais vos contarey de seu saber, que con-os livros que el ten faz: manda-os ante sy todos trager, e pois que fode per eles assaz, se molher acha que o demo ten, 
assy a fode per arte e per sén, que saca dela o demo malvaz.

E, con tod' esto, aynda faz al con-os livros que ten, per bõa fe:

Se acha molher que aja mal deste fogo que de san Marçal é, assy [a] vay per foder encantar que, fodendo, lhi faz ben semelhar que é geada ou nev' e non al.

\section{Comentario}

Vituperio xocoso do deán da catedral de Cádiz, afeccionado á literatura pornográfica e asiduo practicante do sexo e a maxia. A cidade de Cádiz foi conquistada e refundada por Afonso o Sabio en 1262, pouco despois da toma de Alcanatif, que foi rebautizada como Puerto de Santa María (1260). Pouco despois, a cidade pasou a ser sede episcopal. Está documentado un deán de Cádiz, Roy Diaz, que tal vez tivo algún desencontro co rei que provocou esta sátira subida de ton, en que a imaxe do clero non sae moi ben parada.

\section{Notas}

dos sous: dos seus

macar na Ley muyt'á leer [mester]: aínda que lle cómper estudar moito as leis (canónicas)

a que non faça que semelhen grous /...: a que non faga que lle semellen os corvos grous e as enguías vermes da seda (isto é, que non faga alucinar).

do que nos livros que el ten jaz: do que se contén nos libros que el ten.

e pois que fode per eles assaz: e despois de que fode grazas a eles dabondo

per arte e per sén: con arte e con saber

Se acha molher que aja mal /...: se atopa unha muller que padeza do fogo de san Marzal, encántaa mediante o sexo, e faille crer que é xeada ou neve e non outra cousa. Clara referencia a prácticas de maxia: o fogo de San Marçal era unha designación popular da eripsela, unha doenza infecciosa da pel, que provocaba unha intensa sensación de frío, seguida de grandes calores. Na cantiga n.ํㅗ1 das CSM esta doenza é descrita en pormenor.

\section{LEAS NA FAMILIA REAL}

\section{GONÇALO EANES DO VIÑAL (V1008)}

Esta cantiga fez don Gonçal'Anes do Vinhal ao infante don Anrique porque dizian que era entendedor da Raynha dona Joana, sa madrasta, e esto foy quando o el rey don Afonso pos fora da terra. 
Sey eu, donas, que deitad' é d' aqui, do reyno, ja meu amigu' e non sey como lhi vay, mais quer' ir a el rey,

chorar-lh'-ey muyto e direy-lh' assy:

«Por Deus, senhor, que vos tan bon rey fez,

perdoad' a meu amigu' esta vez».

Porque o amo tan de coraçon, como nunc' amou amigo molher,

irey ali hu el rey estever,

chorando dos olhos, direy-lh' enton:

«Por Deus senhor, que vos tan bon rey fez,

perdoad' a meu amigu' esta vez».

$\mathrm{E}$, pois que me non val rogar a Deus,

nen os santos non me queren oyr,

irey a el rey mercee pedir

e direy, chorando dos olhos meus:

«Por Deus, senhor, que vos tan bon rey fez,

perdoad' a meu amigu' esta vez,

e por Deus, que vos deu honr' e bondade

a don Anris esta vez [perdoade]».

\section{Comentario}

Gonçalo Eanes do Viñal foi un trobador portugués que fixo unha meteórica carreira na corte de Afonso o Sabio, con quen participou en campañas militares xa nos tempos en que este, aínda infante, conquistou Murcia (1243). Debeu de servir ao monarca en difíciles misións, porque recibiu un importante señorío en Aguilar (Andalucía). Compuxo dúas cantigas relacionadas coas desavinzas entre Afonso e o seu irmán o príncipe Enrique, que acabou sendo expulsado dos reinos (el rey don Afonso o puxo fóra da terra). Ambas teñen forma de cantiga de amigo; nesta, posta en voz de dona Johana de Ponthieu, segunda esposa e viúva de Fernando III; preséntase a Enrique como amante (entendedor) da súa madrasta, quen lle implora ao rei que lle levante o castigo do desterro.

\section{PERO DA PONTE (B1655, V1189)}

Esta cantiga fez Pero da Ponte ao infante don Manuel, que se começa «Mort’é don Martin Marcos», e na cobra segunda o poden entender. 
Mort' é Don Martin Marcos, ay Deus, se é verdade?

Sey ca se el é morto, morta é torpidade, morta é bavequia e morta neiciidade, morta é covardia e morta é maldade.

Se Don Martinh' é morto, sen prez e sen bondade, oy-mais, maos costumes, outro senhor catade; mais non-o acharedes de Roma ata Cidade; se tal senhor queredes, alhu-lo demandade.

Pero un cavaleyro sey eu, par caridade, que vos ajudari' a tolher del soydade; mais [queredes] que vos diga ende ben verdade?: non est rey nen conde, mais é-x' outra podestade, que non direy, que direy, que non direy...

\section{Comentario}

Sátira do segrel compostelán Pero da Ponte contra o infante don Manuel, fillo de Afonso o Sabio, quen se puxera de parte do seu irmán, o futuro rei Sancho IV, no preito sucesorio que este mantivo co monarca. Este preito estoupou a finais da década de 1270 e desembocou na rebelión aberta de Sancho e na deposición de Afonso, quen viviu os dous últimos anos do seu reinado retirado e illado en Sevilla, mentres o seu fillo tomaba as rendas do goberno. A sátira toma forma de parodia dun pranto ou elexía fúnebre - tipo de composición en que Pero da Ponte era especialista- e constitúe unha execración do infante Manuel por persoa interposta, un tal Martin Marcos, cuxa morte da pé para un implacable retrato moral do infante rebelde.

\section{Notas}

morta é bavequia e morta neiciidade: morta é a estupidez e a necidade. sen prez: sen honra.

oy-mais, maos costumes, outro senhor catade: de hoxe en diante, maos costumes, procurade outro señor. alhu-lo demandade: ídeo procurar a outra parte. 


\section{POLÉMICAS SOCIO-LITERARIAS}

14. AFONSO X O SABIO (B485, V68)

Pero da Pont' á feito gran pecado

de seus cantares, que el foy furtar

a Coton, que, quanto el lazerado

ouve gran tempo, el x'os quer lograr,

e doutros muytos que non sey contar,

por que oj' anda vistido e onrado.

E poren foy Coton mal dia nado, pois Pero da Ponte herda seu trobar;

e muy mais lhi valera que trobado

nunca ouvess' el, assy Deus m’ ampar, pois que se de quant' el foy lazerar serve don Pedro e non lhi dá en grado.

E con dereito seer enforcado deve Don Pedro, por que foy filhar a Coton, pois lo ouve soterrado, seus cantares, e non quis ende dar ũu soldo pera sa alma quitar sequer do que lhi avia emprestado.

E porend' é gran traedor provado, de que se ja nunca pode salvar, come quen a seu amigo jurado, bevendo con ele, o foy matar: todo po-los cantares del levar, come é que oj' anda arrufado?

E pois non á quen-no poren retar queyra, seerá oy-mais por min retado.

\section{Comentario}

Sátira de Afonso o Sabio contra o segrel Pero da Ponte, ao que acusa, humoristicamente, de que emborrachou, asasinou e enterrou o trobador Afonso Eanes do Coton para apoderarse das súas cantigas. O rei sentencia que Pero da Ponte debe ser aforcado, porque despois de cometer o crime, nin sequera deu unha esmola pola alma do asasinado. 


\section{Notas}

á feito gran pecado: cometeu un gran pecado.

434 quanto el lazerado / ouve gran tempo: todo o que el traballou durante moito tempo.

el x'os quer lograr: quere aproveitalo para si.

E poren foy Coton mal dia nado: por iso, Coton naceu en mal día.

pois que se de quant' el foy lazerar / ...: pois de todo o que el traballou se lucra don Pedro (da Ponte) e non llo agradece.

e non quis ende dar /...: de todo o que se aproveitou da Ponte, non quixo nin sequera dar unha moeda pola alma de Afonso do Coton.

de que se ja nunca pode salvar: nunca poderá salvarse disto.

come é que oj' anda arrufado: como agora anda fardando.

seerá oy-mais por min retado: será retado por min de hoxe en diante.

\section{AFONSO X O SABIO (B487, V70)}

Pero da Ponte, paro-vos sinal

per ante o Demo do fogo infernal,

porque con Deus, o padre 'spirital,

minguar quisestes, mal per descreestes.

E ben vej' ora que trobar vos fal,

pois vós tan louca razon cometestes.

E pois razon atan descomunal

fostes filhar, e que tan pouco val,

pesar-mi-á en se vos pois a ben sal

ante o Diaboo, a que obedecestes.

E ben vej' ora que trobar vos fal,

pois vós tan louca razon cometestes.

Vós non trobades come proençal,

mais come Bernardo de Bonaval;

e por ende non é trobar natural,

pois que o del e do Dem' aprendestes.

E ben vej' ora que trobar vos fal,

pois vós tan louca razon cometestes.

E poren, don Pedr' en Vila Real,

en maao ponto vós tanto bevestes.

\section{Comentario}

Nova sátira xocosa contra o segrel cortesán Pero da Ponte. Se na anterior é acusado de asasinar e roubar a Afonso Eanes do Coton, nesta é imputado por ser autor dunha composición demoníaca, pero non está claro se ten este carácter polo seu contido relixioso 
(o cal parece improbable) ou é simplemente unha maneira figurada de descualificala hiperbolicamente. En todo caso, a afirmación «vós non trobades come proençal / mais come Bernardo de Bonaval» parece unha censura contra o desvío dos trobadores galegos (ou dos segreis composteláns?) respecto aos moldes occitanos.

\section{Notas}

paro-vos sinal: notifícovos, cítovos perante o demo; trátase dunha expresión xurídica minguar quisestes, mal per descreestes: quixestes faltar, e del renegastes.

E ben vej' ora que trobar vos fal: agora comprobo que non sodes capaz de trobar. pois vós tan louca razon cometestes: pois emprendestes tal loucura.

E pois razon atan descomunal / fostes filhar: xa que vos deu por cometer unha tolería tan enorme, pesar-mi-á en se vos pois a ben sal: hame de amolar se safades ben desta ante o demo.

e por ende non é trobar natural: e por isto non é trobar como é debido.

en Vila Real: pode referirse a Ciudad Real, localidade rebautizada como Vila Real por Afonso en 1255, ou a outra vila de reguengo, como Allariz ou Ribadavia.

\section{AFONSO EANES DO COTON / PERO DA PONTE (B969, V556)}

Pero da Ponte e Afons' Eanes fezeron esta tenzon

-Pero da Pont', en un vosso cantar

que vós ogano fezestes d' amor, fostes-vos hy escudeyro chamar.

E dized' ora tant', ay, trobador: pois vos escudeyro chamastes hy, por que vos queixades ora de min, por meus panos, que vos non quero dar?

-Afons' Anes, se vos én pesar, tornade-vos a vosso fiador; e de m'eu hy escudeyro chamar, e por que non, pois escudeyro for? E se peç' algo, vedes quant' á hy: non podemos todos guarir assy come vós, que guarides per lidar.

-Pero da Ponte, quen a mí veer desta razon ou doutra cometer, querrey-vo-lh' eu responder, se souber, como trobador deve responder: en nossa terra, se Deus me perdon, 
a todo escudeyro que pede don

as mais das gentes lhe chaman segrel.

-Afons' Anes, est' é meu mester,

e per esto dev' eu guarecer

e per servir donas quanto poder;

mais [hy] ũa ren vos quero dizer:

en pedir algo non digu' eu de non

a quen entendo que faço razon,

e alá lide quen lidar souber.

-Pero da Ponte, se Deus vos perdon, non faledes mais en armas, ca non

vos está ben, esto sabe quen-quer.

-Afons' Anes, filharey eu don,

é verdad', e vós, ay cor de leon?

E faça quis-cada-quen seu mester.

\section{Comentario}

Debate poético (tenzón) entre o trobador galego Afonso Eanes do Coton e o segrel Pero da Ponte, os dous involucrados nunha cantiga satírica de Afonso o Sabio. O interesante do texto é o debate sobre a definición dos respectivos status socioculturais, o do cabaleiro trobador e do escudeiro segrel. Afonso do Coton pregúntalle a Pero da Ponte por que se queixa de que el non o retribúa polo seu oficio (era moi común pagar con panos), tendo en conta de que se reivindica como escudeiro e trobador, por tanto, cultivador desinteresado da arte do trobar. Pero da Ponte respóndelle que el non vive da guerra, coma Afonso do Coton (guarides por lidar). Afonso replica que un escudeiro que troba a cambio de paga (escudeiro que pede don) «en nossa terra» (Galicia? a terra de Santiago? España?) é denominado segrel. Pero da Ponte continúa reivindicando o seu dereito a ser retribuído polo seu trobar. Afonso remate rogándolle ironicamente que non fale de armas, que non lle acae, e no retruque final, Pero da Ponte búrlase de Afonso alcumándoo humoristicamente de Cor de León (corazón de León).

\section{Notas}

por que vos queixades ora de min / ...: por que vos queixades de que non vos pague cos meus panos? se vos én pesar / tornade-vos a vosso fiador: se vos amola, queixádevos a quen volos fiou (insinuando que os panos de Coton son de fiado).

E se peç' algo, vedes quant'á hy: se pido algo a cambio de trobar, explico por que o fago.

non podemos todos guarir assy: non todos podemos gañar a vida así.

come vós, que guarides per lidar: coma vós, que vivides de facer a guerra.

desta razon ou doutra cometer: atacáronme con estes ou con outros argumentos. 
a todo escudeyro que pede don: a todo escudeiro que pide paga. esto sabe quen-quer: isto sábeo todo o mundo.

filharey eu don: recibirei pagamento.

E faça quis-cada-quen seu mester: e cada un faga o que lle pete.

\section{JOHAN PEREZ DE AVOYN CON LOURENÇO (V1010)}

-Lourenço, soýas tu guarecer

como podias, per teu citolon,

ou ben ou mal, non ti digu' eu de non,

e vejo-te de trobar trameter;

e quero-t' eu desto desenganar:

ben tanto sabes tu que é trobar

ben quanto sab' o asno de leer.

-Johan d' Avoyn, ja me cometer

veeron muytos por esta razon

que mi dizian, se Deus mi perdon,

que non sabia 'n trobar entender,

e veeron poren comigu' entençar,

e figi-os eu vençudos ficar

e cuydo-vos deste preito vençer.

-Lourenço, serias muy sabedor,

se me vencesses de trobar nen d' al,

ca ben sey eu quen troba ben ou mal,

que non sabe mais nẽhun trobador;

e por aquesto te desenganey;

e vês, Lourenço, onde cho direy:

quita-te sempre do que teu non for.

- Johan d' Avoyn, por Nostro Senhor,

por que leixarey eu trobar atal

que muy ben faç' e que muyto mi val?

Des hy ar gradece-mi-o mia senhor,

porque o faç'; e, pois eu tod' est' ey,

o trobar nunca o eu leixarey,

poi-lo ben faç' e ey hy gran sabor.

\section{Comentario}

Tenzón satírica entre o trobador portugués Johan Perez de Avoyn, un dos magnates máis sobranceiros da corte de Afonso III O Bolonhês, e o xogral Lourenço, un dos máis 
produtivos e polémicos dos representados nos cancioneiros. Johan de Avoyn, en ton humorístico, concede que Lourenço viva do seu oficio como executante (guarecer per teu citolon), pero pretende disuadilo de que se dedique a trobar. Lourenço, en ton desafiante gábase da súa competencia no trobar (que muy ben o faço), e advirte que non vai deixar, porque lle gusta (ey hy gran sabor) e porque llo agradece a súa dona.

\author{
Notas \\ soýas tu guarecer: antes gañabas a vida, como podías, co teu citolón; nótese o aumentativo de cítola \\ e vejo-te de trobar trameter: vexo que te entremetes no trobar \\ ja me cometer / veeron muytos: xa me viñeron atacar moitos \\ e veeron poren comigu' entençar: viñeron por iso a disputar en tenzón \\ e figi-os eu vençudos ficar: deixeinos vencidos \\ e cuydo-vos deste preito vençer: coido que vos vou vencer nesta discusión \\ se me vencesses de trobar nen d' al: se me vencess en trobar ou noutra cousa \\ e vês, Lourenço, onde cho direy /...: polo que eu cho direi \\ Des hy ar gradeçe-mi-o mia senhor: ademais, agradécemo a miña señor \\ poi-lo ben faç' e ey hy gran sabor: xa que o fago ben e gústame moito
}

\title{
V. TRISTURA NA CORTE E FUXIDA DO MUNDO
}

18. GIL PEREZ CONDE (B1525)

Non é Amor en cas del Rey, ca o non pod' om' y achar aa cea nen ao jantar; a estas oras o busquey nas pousadas dos privados; preguntey a seus prelados por Amor, e non-o achey.

Tẽen que o non sab’ el Rey que Amor aqui non chegou, que tant' ogano del levou e non vẽo; ben-o busquey nas tendas dos infanções e nas dos de criações, e hy dizen todos «non sey».

Perdud' é Amor con el Rey, porque nunca en hoste ven, pero xe del[e] algo ten.

Direy-vos eu hu o busquey: 
antr' estes freyres tempreyros,

ca ja os espitaleyros

por Amor non preguntarey.

\section{Comentario}

Esta cantiga de Gil Perez Conde, trobador portugués activo nas corte de Afonso o Sabio e Sancho IV, semella reflectir o ambiente tenso e depresivo da corte do primeiro nos seus últimos anos, cando o seu propio fillo Sancho se rebelara contra el. A referencia final aos Templarios é significativa, pois foi a única orde militar que se mantivo fiel ao monarca ata os seus derradeiros días. Nesta cantiga, Amor debe ser entendido non no sentido erótico, senón no de solidariedade e e concordia.

\section{Notas}

ca o non pod' om' y achar: non se pode atopar alí

Tẽen que o non sab' el Rey: coidan que non sabe o rei

Infanções: infanzóns, cabaleiros nobres

Criações: cabaleiros novos, criados na corte.

Hu o busquey: onde o busquei.

Antr' estes freyres tempreyros / ca ja os espitaleyros /...: entre os freires templarios (da Orde do Temple), porque aos hospitalarios (da Orde do Hospital) / por Amor non preguntarei.

\section{AFONSO O SABIO (B480, V63)}

Non me posso pagar tanto

do canto

das aves nen de seu son,

nen d' amor nen de misson

nen d' armas, ca ey espanto,

por quanto

muy perigoosas son,

-come dun bõo galeon,

que mi alongue muyt' aginha

deste demo da canpinha,

hu os alacrães som;

ca dentro no coraçon

senti deles a espinha!

E juro par Deus lo santo

que manto

non tragerey nen granhon,

nen terrey d' amor razon 
nen d' armas, porque quebranto

e chanto

440 ven delas toda sazon;

mais tragerey un dormon

e irey pela marinha

vendendo azeit' e farinha;

e fugirey do poçon

do alacran, ca eu non

lhi sey outra meezinha.

Nen de lançar a tavolado

pagado

non sõo, se Deus m' ampar,

a treo, nen de bafordar;

e andar de noute armado,

sen grado

o faço e a roldar;

ca mais me pago do mar

que de seer cavaleyro;

ca eu foy ja marinheyro

e quero-m' oy-mais gardar

do alacran, e tornar

ao que me foy primeyro.

E direy-vos ũu recado:

pecado

ja me non pod' enganar

que me faça ja falar

en armas, ca non m’é dado

-doado

m’é de as eu razõar,

pois las non ey a provar-;

ante quer' andar sinlheyro

e ir come mercadeyro

algũa terra buscar,

hu me non possan culpar

alacran negro nen veyro.

\section{Comentario}

Este é unha das cantigas máis célebres dos cancioneiros galego-portugueses. Orixinal e desconcertante, traballada sobre os tópicos do «contemptus mundi» e da «fuga 
mundi», o poema ten sido obxecto de interpretacións moi diversas, desde quen o le en termos autobiográficos ata quen, no extremo contrario, o considera un puro artificio (edición, comentario e discusión en Paredes 2010: 187-195, con remisión á bibliografía máis importante; véxase tamén del Río Grande 2018). A voz poética do rei expresa o seu desengano e o desexo de abandonar a vida que leva, propia dun cabaleiro: renuncia ao amor e ás armas e anuncia a súa decisión de fuxir por mar para vivir como mercadeiro, vendendo aceite e fariña. A chave da composición está no motivo que o apuxa a tan drástica decisión: librarse dos alacráns que o rodean e do seu veneno, unha referencia a penas encuberta á deslealdade e traizón, probablemente dos nobres e de varios dos seus familiares.

\section{Notas}

Non me posso pagar tanto: Xa non me podo deleitar.

nen de misson: nin de campañas militares.

ca ey espanto: pois téñolles medo.

que mi alongue muyt' aginha: que me aparte axiña

nen granhon: nin barba (que adoitaban levar os cabaleiros).

nen terrey d' amor razon: nin falarei de amor

chanto: pranto.

toda sazon: sempre.

mais tragerey un dormon: levarei unha barca.

e fugirey do poçon: fuxirei do veneno.

Nen de lançar a tavolado: Tampouco me apetece lanzar ao taboado (entretemento militar).

a treo, nen de bafordar: practicar o bafordo (un exercicio de armas); a treo é forma restaurada.

e andar de noute armado /...: andar de noite armado, a facer roldas, fágoo a contragusto. oy-mais: de hoxe en diante.

tornar / ao que me foy primeyro: volver ao que fun primeiramente.

E direy-vos ũu recado /...: Dareivos unha expliacación: o pecado xa non me pode enganar para facerme falar de armas, pois non me toca- éme de balde falar delas, pois nunca as vou probar.

ante quer' andar sinlheyro: prefiro andar solitario

hu me non possan culpar /...: onde non me poida trabar, alacrán negro nin pinto. 


\section{GABANZA DO REI E DO SEU «FEITO DO IMPERIO»}

20. JOHAN VASQUIZ DE TALAVEYRA/PEDRO AMIGO DE SEVILLA (B1550)

-Ay Pedr’ Amigo, vós que vos tẽedes

por trobador, agora o verey

eno que vos ora preguntarey

e no recado que mi tornaredes:

Nós, que avemos muy bon Rey por senhor

e no-lo alhur fazen enperador,

dizede-mi ora quant' y entendedes.

-Johan Vaasquiz, pois me cometedes, direy-vos eu quant' y entend' e sey: pois nós avemos aquel melhor Rey que no mund'á, ¿por que non entendedes que o seu prez e o seu valor todo noss' est, poys enperador for? O demo lev' o que vos hy perdedes!

-Ay Pedr' Amigo, eu non perderia en quant' el Rey podesse mais aver en bõa terra e en gran poder, ca quant' el mais ouvesse, mais valria. Mais perde o Reyn' e vos perdedes hy, os que sen el ficaredes aqui, pois que s' el for d' Espanha sa via.

-Johan Vaasquiz, eu ben cuidaria que o Reyno non á por que perder por el Rey nosso senhor mais valer, ca Rey do mund' é. Se se vay sa via valrá el mais, e ar nós per el hy.

Demais quis Deus que ten seu filh' aqui, que se s' el for, aqui nos leixaria.

-Ay Pedr' Amigo, pois vos ja venci desta tençon que vosco cometi, nunca ar migo filhedes perfia.

-Johan Vaasquiz, sey que non é assy desta tençon, ca errastes vos hy e diss' eu ben quanto dizer devia. 


\section{Comentario}

Gabanza do rei Afonso e do seu «feito do Imperio» tecida en forma de tenzón entre dous trobadores que frecuentaron a súa corte: o castelán Johan Vasquiz e o galego Pedro Amigo de Sevilla, probablemente composta pouco antes da viaxe do monarca a Beaucaire para entrevistarse co Papa nunha derradeira tentativa, fanada, de conseguir o apoio deste para a súa ambición imperial.

\section{Notas}

no-lo alhur fazen enperador: e nolo fan emperador outrures, noutra terra (alhur). quant' y entend' e sey: canto entedo e sei do assunto $(y)$.

ca quant' el mais ouvesse, mais valria: canto o rey máis tivese, máis valería.

Se se vay sa via / valrá el mais, e ar nós per el hy: se marcha, valerá el mais e, e nós tamén por el.

desta tençon que vosco cometi /...: xa que vos vencín nesta tenzón que fixen convosvo, nunca máis discutades comigo.

Ca errastes vos hy: porque vos errastes no asunto (ao afirmar que o reino e os súbditos perdían coa marcha do rei).

\section{UNHA AUTOBIOGRAFÍA POÉTICA E POLÍTICA}

\section{CANTIGAS DE SANTA MARÍA, CÓDICE DOS MÚSICOS, N. 235}

Esta é como Santa Maria deu saude al Rey don Afonso

quando foi en Valadolide enfermo que foi juygado por morto.

Como gradecer ben-feito / é cousa que muito val, assi quen non-o gradece / faz falsidad' e gran mal.

E daquest' un gran miragre / vos direi desta razon, que avẽo a don Afonso / de Castel' e de Leon Rei, e da Andaluzia / dos mais reinos que y son; e, por Deus, parad'y mentes /e non cuidedes en al.

Aqueste Santa Maria / mui de coraçon de pran loava mais doutra cousa, / e non prendia afan en servi-la noit' e dia, / rogando seu bon talan que morress' en seu serviço, / poi-lo seu ben nunca fal.

E desto que lle pedia / tan muito a aficou por esto, que ũa noite / en soños llo otorgou, ond' ele foi muit' alegre,/ tanto que s' el espertou, e loou porend' a Virgen,/ a Señor espirital. 
Pois passou per muitas coitas / e delas vos contarei: Ũa vez dos ricos-homes/ que, segundo que eu sei, se juraron contra ele / todos que non fosse Rey, seend' os mais seus parentes, / que divid' é natural,

E demais, sen tod' aquesto, / fazendo-lles muito ben, o que lle pouco gracian / e non tiỹan en ren; mais conortou-o a Virgẽ / dizendo: «Non dês poren nulla cousa, ca seu feito / destes é muy desleal.

Mas eu o desfarei todo / o que eles van ordir, que aquelo que desejan / nunca o possan conprir; ca meu fillo Jesu-Cristo / sabor á de se servir, e d'oi-mais mui ben te guarda / de gran pecado mortal».

Tod' aquesto fez a Virgẽ, / ca deles ben o vingou; e despois, quand' en Requena / este Rey mal enfermou, u cuidavan que morrese, / daquel mal ben o sãou; fez por el este miragre / que foi começ' e sinal Dos bẽes que lle fezera / e lle queria fazer. E depois, quando da terra / sayu e que foi veer o Papa que enton era, / foi tan mal adoecer que o teveron per morto / dest' anfermidad' atal.

E pois a Monpisler vẽo / e tan mal adoeceu que quantos fisicos eran, / cada ũu ben creeu que sen duvida mort' era; / mas ben o per guareceu a Virgen Santa Maria, / como Señor mui leal. E feze-ll' en poucos dias / que podesse cavalgar e que tornass' a sa terra / por en ela ben sãar; e passou per Cataloña, / en que ouve de fillar jornadas grandes no dia, / como quen and' a jornal. E pois entrou en Castela, / vẽeron todos aly, toda-las gentes da terra, / que lle dizian assy: «Sennor, tan bon dia vosco». / Mas depois, creed' a my, nunca assi foi vendudo / Rey don Sanch’ en Portugal,

Ca os mais dos ricos-omes / se juraron, per com' eu sei, por deitaren do reyno / e que ficasse por seu, que x'o entre si partissen; / mas de fazer lles foi greu, ca Deus lo alçou na cima / e eles baixou no val. 
E depois, quand' en Bitoira / morou un an' e un mes, jazendo mui mal doente, / contra el o Rey frances se moveu con mui gran gente; / mas depois foi mais cortes,

ca Deus desfez o seu feito / com' agua desfaz o sal.

E depois de muitos maes / o sãou, grandes e greus, que ouve pois en Castela, / u quis o Fillo de Deus que fillasse gran vingança / daqueles que eran seus ẽemigos e pois dele. / E ben com' ard' estadal

Ardeu a carne daqueles / que non querian moller; os outros pera o demo / foron e, se Deus quiser, assi yrá tod' aquele / que atal feito fezer, e do mal que lles én veña, / a mi mui pouco m’ incal.

E pois sayr de Castela, / el Rey con mui gran sabor ouve d' ir aa fronteira; / mas a mui bõa Sennor non quis que enton y fosse / se non sãasse mellor; porend' en todo o corpo / lle deu febre gẽeral.

E con est' anfermidade / das outras sãar o fez; e u cuidavan que morto / era, foi-se dessa vez dereit' a Valedolide, / u a Sennor mui de prez o guariu do que ficara. / Mas ante quis que en tal

Ponto vẽess' a seu feito, / que non ouvess' y joyz que de vida o julgasse, / e a Sant' Anperadriz lle fez ben sentir a morte; / mais eno dia fiiz de Pasqua quis que vivesse, / $\mathrm{u}$ fazen o ciro pasqual.

E ar foy-o conortando, / ca maltreit' era assaz, e de todas sas doores / o livrou ben e en paz, tragendo per el sas mãos, / e non tiinna enfaz e parecia mas crara / que é rubi nen crestal.

E tod' aquesto foi feito / dia de Pascua a luz per ela e per seu Fillo, / aquel que seve na cruz que tragia nos seus braços, / que pera nos sempr' aduz a sa merce' e sa graça / no perigo temporal.

Tod' aquesto faz a Virgen, / de certo creed' a min, pera dar-nos bõa vida / aqui e pois bõa fin; e porende a loemos / que nos meta no jardin de seu fill' e que nos guarde / do mui gran fog' yfernal. 
Como gradecer ben-feito / é cousa que muyto val, assi quen non-o gradece / faz falsidad' e gran mal.

\section{Comentario}

Nas Cantigas de Santa María atópanse unha serie de composicións que teñen un carácter autobiográfico, ou ben que contan episodios da vida de familiares de Afonso o Sabio. Unha das máis notables, e talvez a que ten un contido político máis explícito, é a que se reproduce aquí. Só figura nun dos códices, o máis amplo (E). A composición foi obxecto dun minucioso estudo sobre os feitos históricos que nela se relatan (Kinkade 1992). Este investigador subliña que a orde cronolóxica en que se presentan os acontecementos que máis relevantes da súa vida entre 1269 e 1279, o período talvez máis crucial do seu reinado, durante o cal se sucederon unha serie de infortunios para Afonso o Sabio: a traizón dos seus familiares, as conspiracións, revoltas e abandono das obrigas feudais de moitos dos aristócratas máis empoleirados dos seus reinos (os ricos-omes), unha sucesión de cinco terribles doenzas, a renuncia da súa reclamación do trono do Sacro Imperio por causa da oposición do Papa. Neses anos tamén se produciron as mortes do seu primoxénito e herdeiro, Fernando, e da súa filla Leonor, que son evocadas indirectamente («depois de muitos maes [...] grandes e greus»).

Tamén hai unha referencia a un acontecemento atroz, que foi a condena á morte que Afonso impuxo ao seu propio irmán, Fradique (esganado) e ao seu cuñado Simon Ruiz de los Cameros, queimado vivo (1277), condena que na cantiga se motiva pola acusación de manteren relacións homosexuais: «E ben com’ ard’ estadal / Ardeu a carne daqueles / que non querian moller», aínda que a realidade histórica parece máis complexa (Kinkade 1992: 315-318). Significativamente, lémbrase tamén a traizón que padecera o rei de Portugal, Sancho II, quen Afonso, aínda infante, tentara apoiar, sen suceso, fronte á rebelión dos nobres alentada pola Igrexa e encabezada polo seu propio irmán. Como o propio Kinkade indica, as palabras chave desta composición son traizón e ingratitude, ás que se podería engadir deslealdade.

\section{Notas}

foi juygado: foi xulgado, foi tido.

parad'y mentes /e non cuidedes en al: estade atentos e non pensedes noutra cousa.

de pran: realmente.

e non prendia afan: non se cansaba.

seu bon talan: con toda a alma.

poi-lo seu ben nunca fal: o ben da Virxe nunca falla.

tan muito a aficou: tanto lle insistiu.

que divid' é natural: os seus parentes están naturalmente obrigados (en débeda) con el.

o que lle pouco gracian / e non tiỹan en ren: pouco llo agradecían e non o tiñan en conta.

Non dês poren / nulla cousa: Non te preocupes por isto, non lle deas importancia. 
ordir: urdir.

sabor á de se servir: gústalle axudar.

d'oi-mais: desde agora.

u cuidavan que morrese: onde coidaron que ía morrer.

en que ouve de fillar: onde tivo que facer

por deitaren do reyno / e que ficasse por seu: os ricos-omes conxuráronse para expulsalo do reino e apoderarse deste.

de fazer lles foi greu: foilles imposible.

u quis o Fillo de Deus: onde quixo o Fillo de Deus.

E ben com' ard' estadal: así como arde un estadal.

e do mal que lles én veña, /...: do mal que lles veña (aos que van ao inferno) a min tanto me ten.

o guariu do que ficara: o curou do mal que lle quedara.

que non ouvess' y joyz /...: que non houbese xuíz que xulgase a súa vida (que non morrese).

u fazen o ciro pasqual: o día de Pascua, cando se acende o cirio pascual.

E ar foy-o conortando, / ...: e tamén o foi confortando, porque estaba moi maltreito.

e non tiinna enfaz: que non levaba veo (que lle cubrise a cara).

que seve na cruz: que estivo na cruz.

que pera nos sempr' aduz: que nos trae para sempre. 
